號四十五的二第誌雜會學類人景東

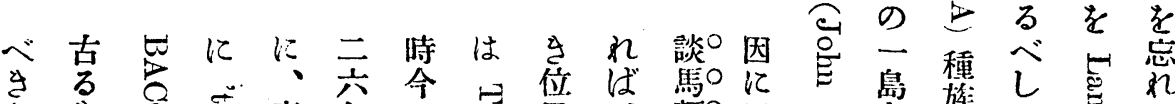

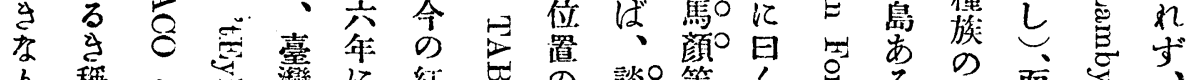
b、稱 の

、呼名

一 馬。

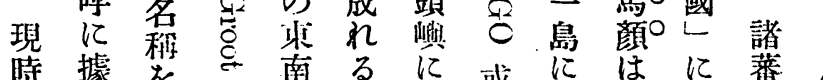

西據

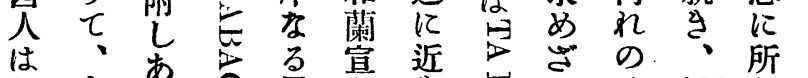

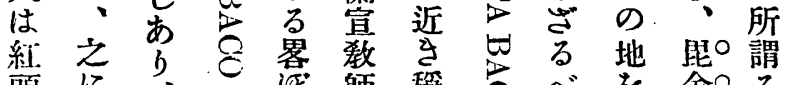

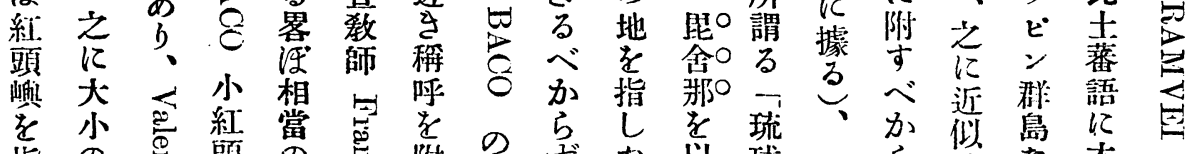

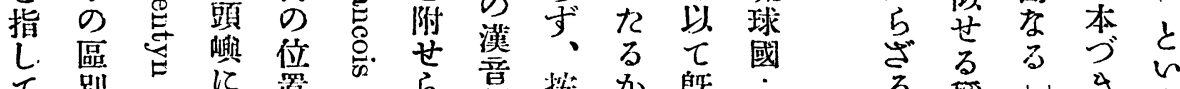
七 别はに置

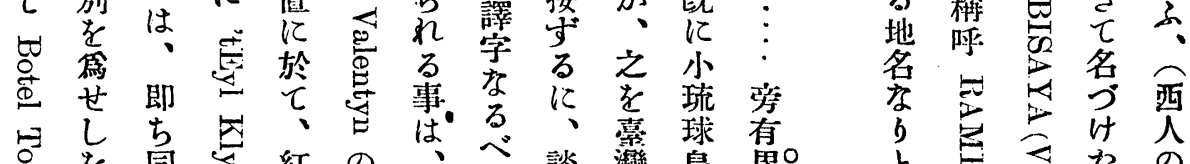

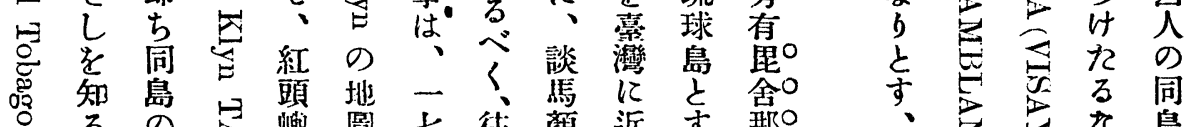

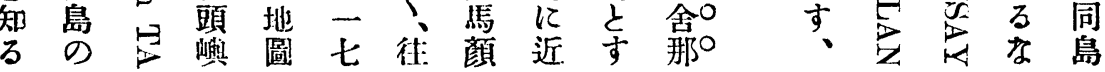

ベくあ分

九 違る 類

其合け の

の加化

違 らど下

方 磨

此頭丙 $\tau$ 蕃。蕃

處蓋 - 南 頭 $人$

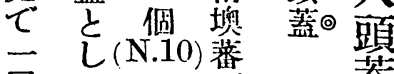

層ては頭

明别他 七

に種の個

なに六は

るし倜何

他 置 は

三 $\begin{array}{llll}\text { 六 } & \text { 頭 } & \text { 中 } \\ \text { 等 }\end{array}$

個云 の 簧太

はふ狀の

互 事 態 頙 郎

に老㔔で

似述全は 圆あイb灣此訛彼同之

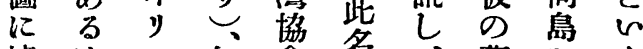

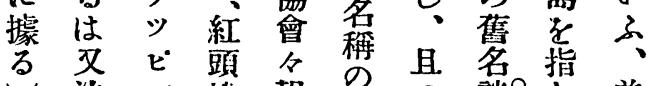

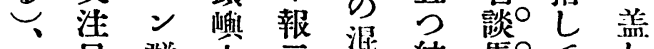

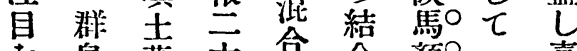

島蕃六合合顔山喜

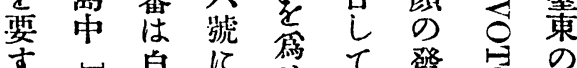

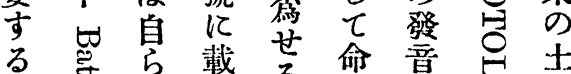

る

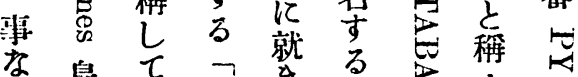

る 息 て 紅

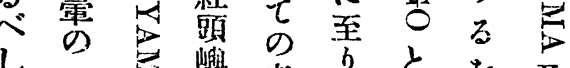

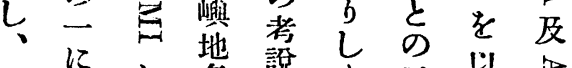

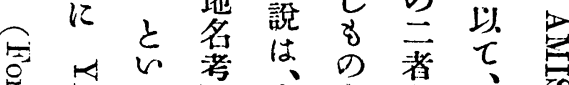

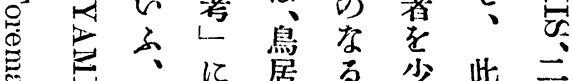

导而詳居腒少蹯族

の-し少のしく語は

地島、てな器、轉と 
日十二月五等十四治明

今固 $\bigcirc$ 南とな大比渄加て (N.8)探の山し女よて 次て $(\mathrm{N} .10)$ 墺 共 にあは蕃にけく的は、N.S ら びしに置あ 大る

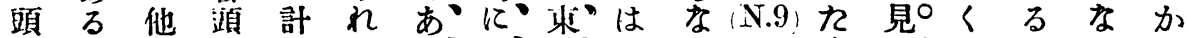

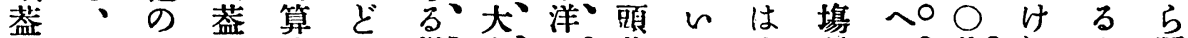

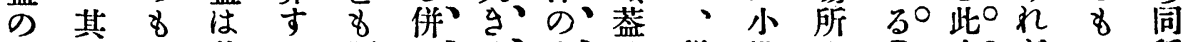

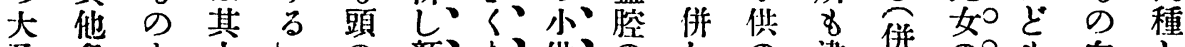

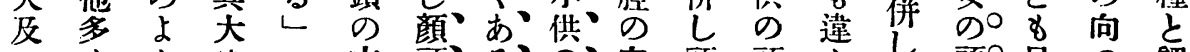

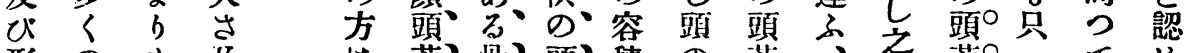

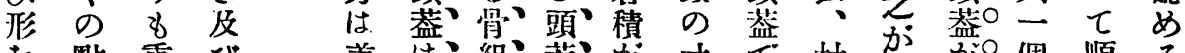

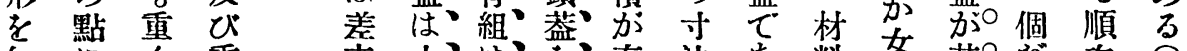

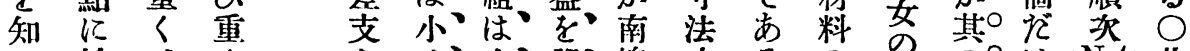

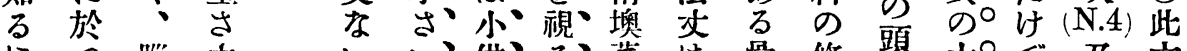

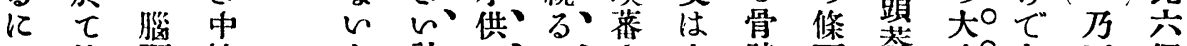

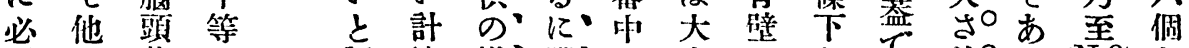

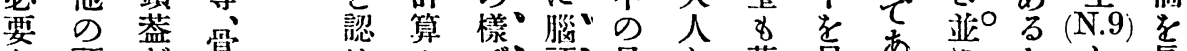

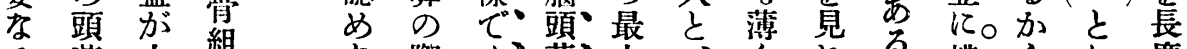

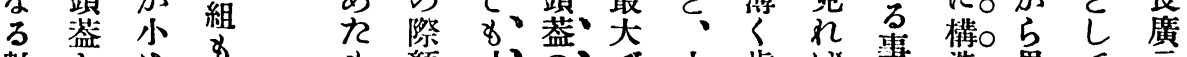

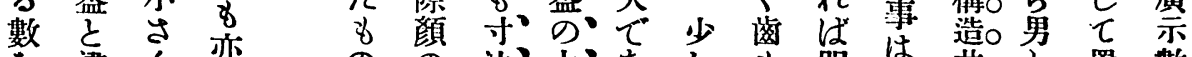

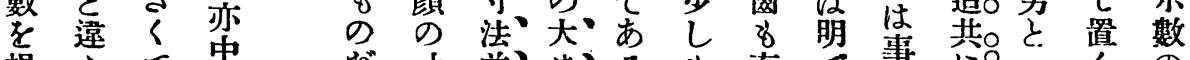

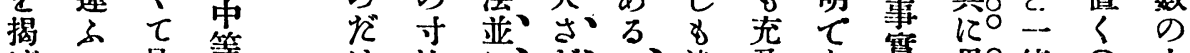

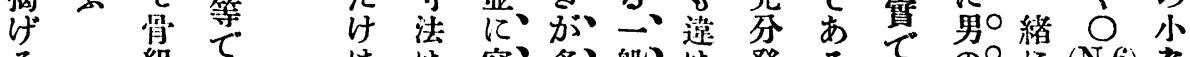
る 組あでは容名般は發る で の○に (N.6)な

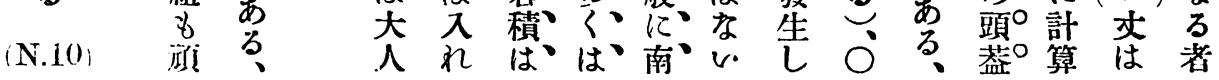

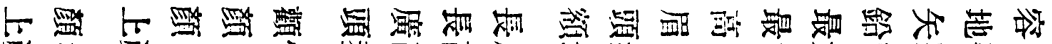

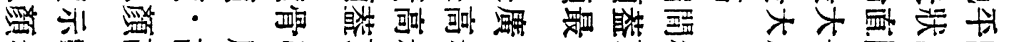

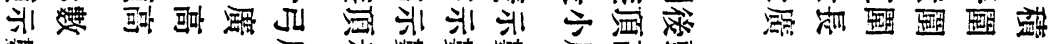
䗬

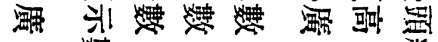

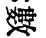

惭

知㘳

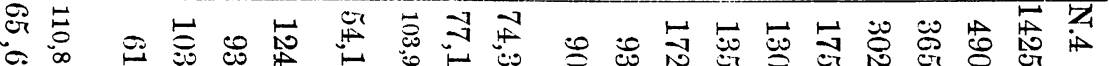
3)

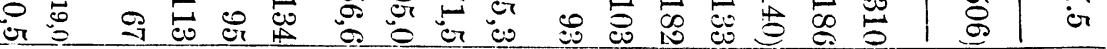

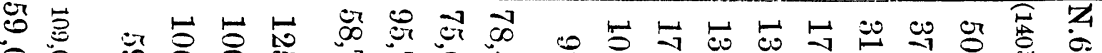

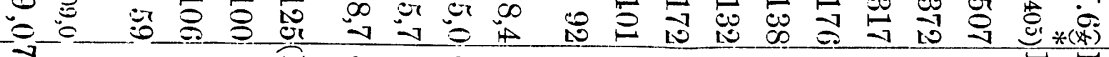

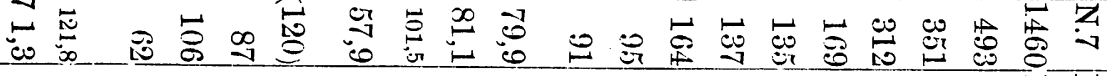

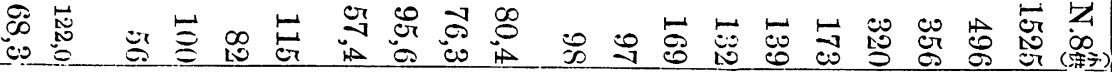

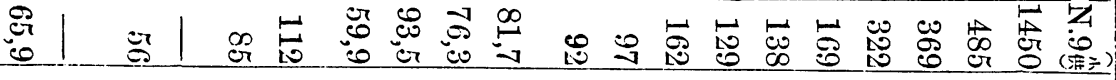
Cᄀ

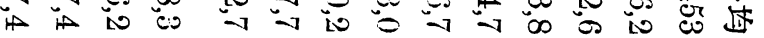

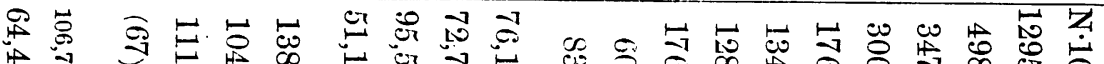


號四十五百二第誌雜會學類人京東

つる小

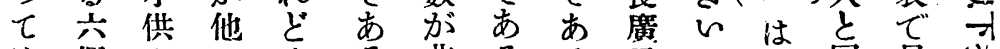
は個ののるる非るる示し矢同見鞋

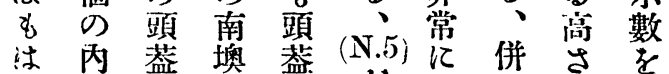

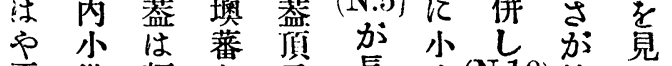
本 供顏主 長 さ(N.10) 餘方

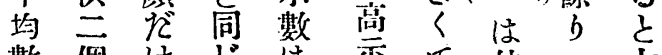

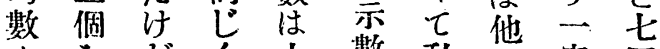

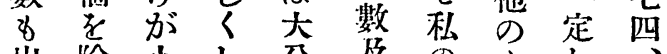

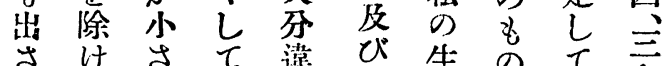
な゙売

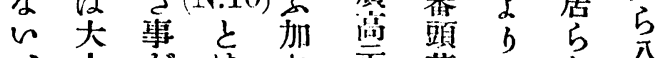

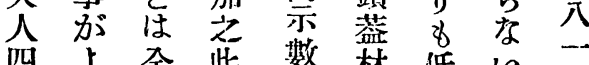
四尘全 $($ 此 整 林低

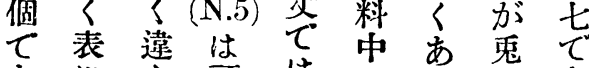

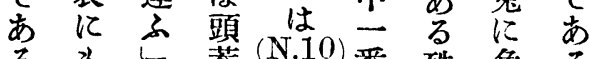

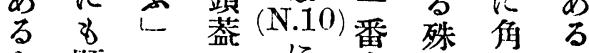

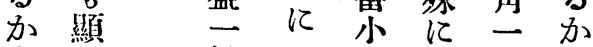
ら 般近 頭般

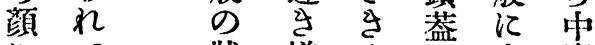

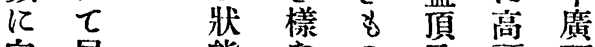
向居態なの 示頭頡

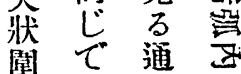
庋 あ $b$ びる 小 鉛加供 9 䡩 5 ब

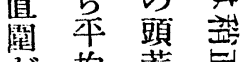

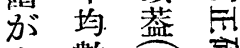
小 數 $\widehat{\mathrm{N}, \mathrm{S}}$ 窟

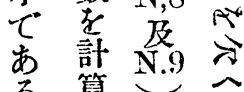
方算 從允基

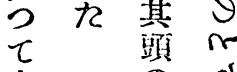

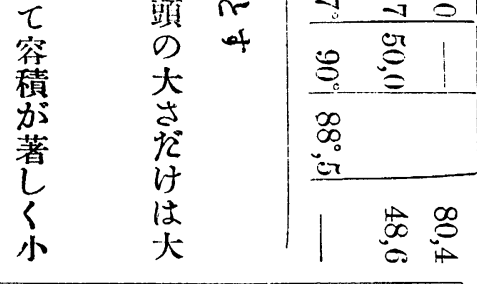

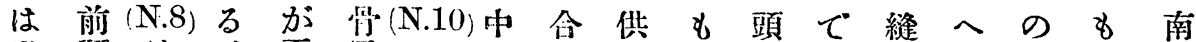
發頭は、雨弓は二に示蓝あ合此文低墺 肖結前侧少顴番廣大供艺るは頭のく 蕃

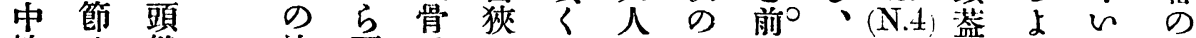

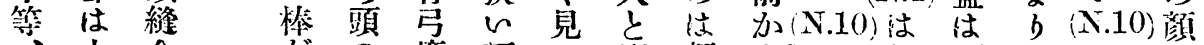

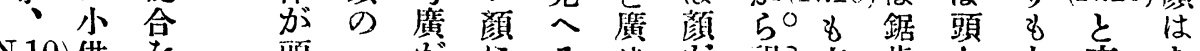

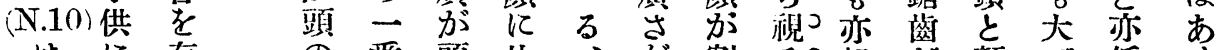

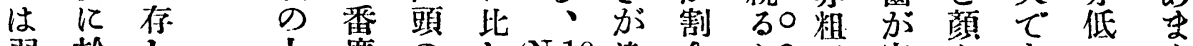

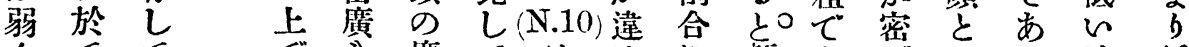

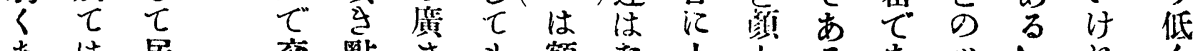

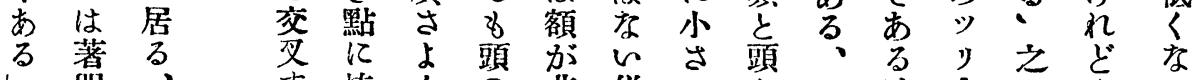

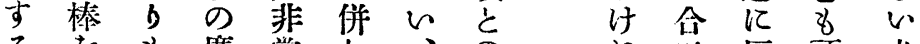

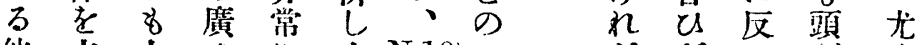
他立大 のう でに 狹 供はり

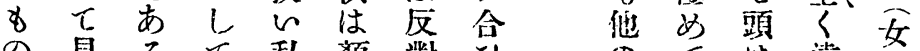

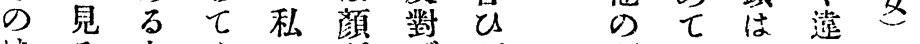

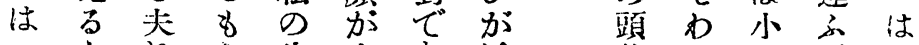

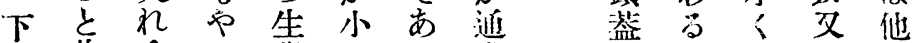

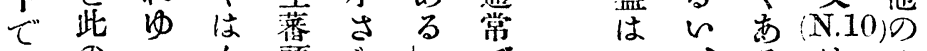

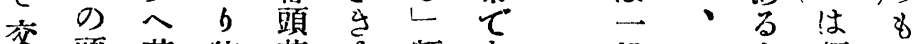

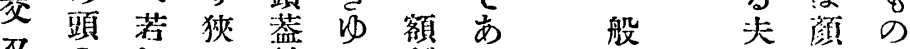

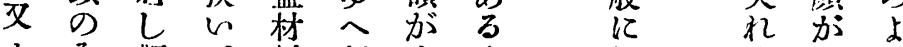

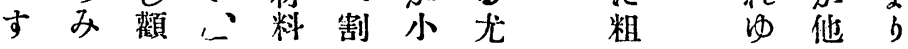




\section{日十二月五. 年十四治明}

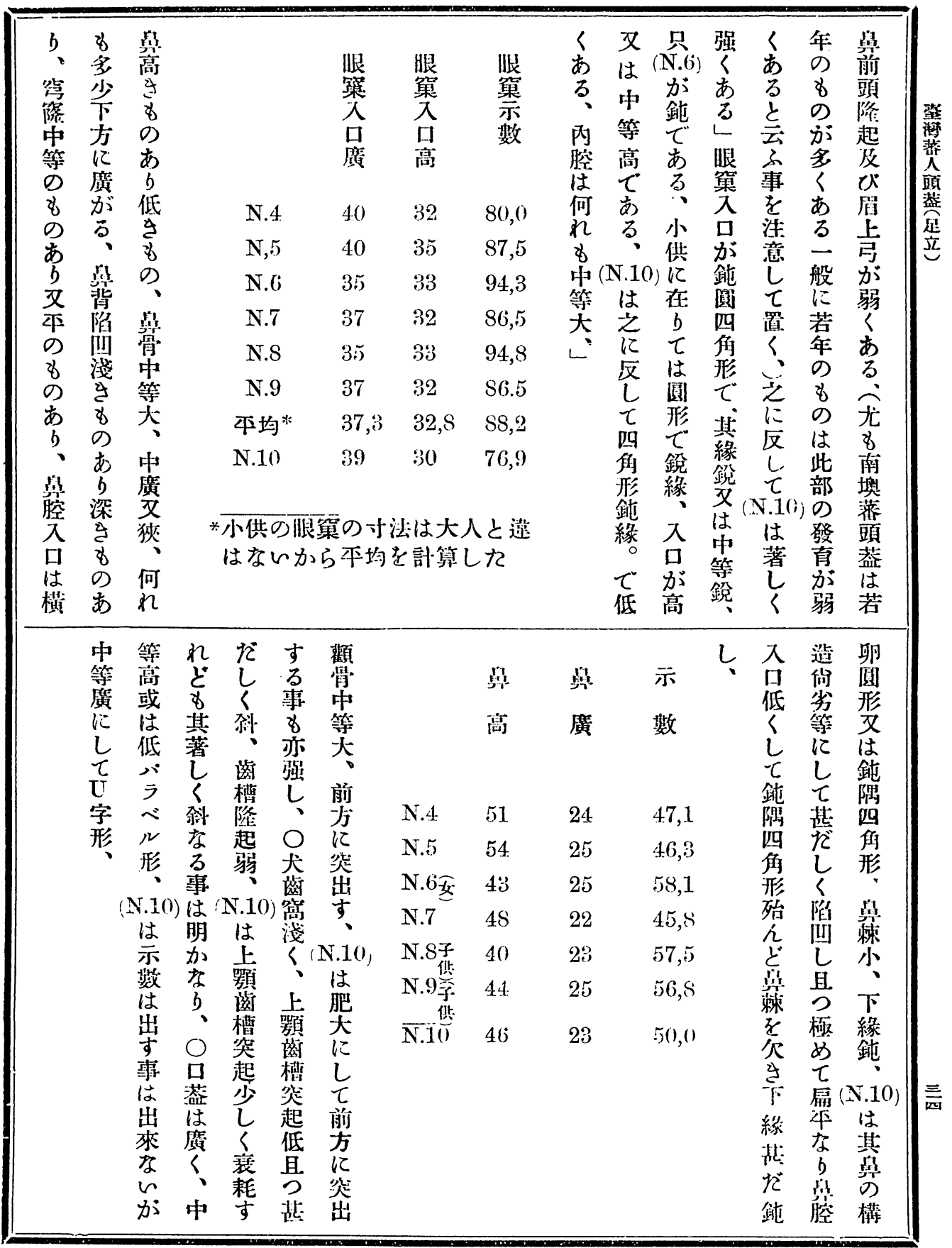


號四十五百二第誌雜會學類人京東

bト 科に 頭 節 は 等 頭

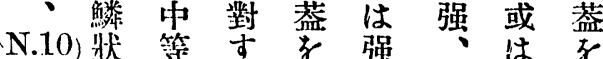

は部、る 側 虫 $(\mathrm{N} .10)$ 弱圭。

前 の 後傾. 面○市 は 加

頭 弦 頭 斜 $2^{\circ} b$ 前 但 $5^{\circ}$

骨 は 骨中 bo 弱頭

穹上穹 等 視 出部小る。

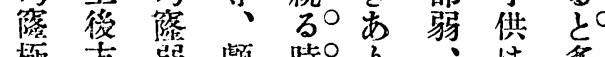

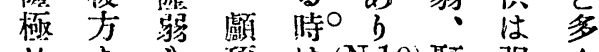

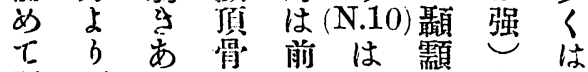

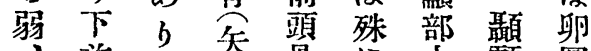

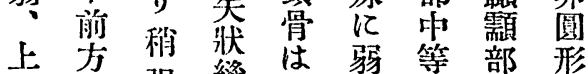

鱗 方 强 綎 其

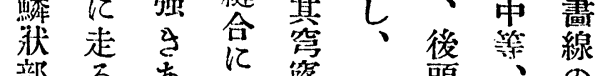

部万古於管頭、可

の方 方於都後爷

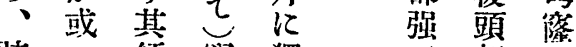

弦は傾器獨・部は

上领斜管乙

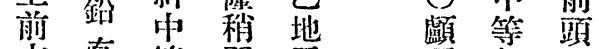

方 直等 弱 本 頂 部 部

よな、傾線結或中

$\begin{array}{ll}\text { 口 } & \text { 口 } \\ \text { 䒺 } & \text { 莨 } \\ \text { 長 } & \text { 廣 }\end{array}$

口

蓝

數

N.4 41

36

87,8

N.5

46

40

87,0

N.6

44

11

93,2

N.7

39

39

40

35

100,0

N.S

38

33

87,5

N.9

N.10

(50)

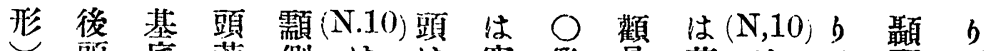

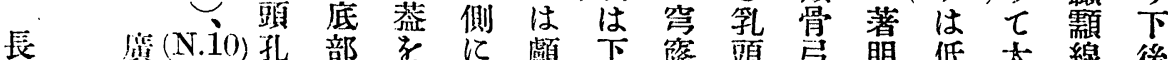

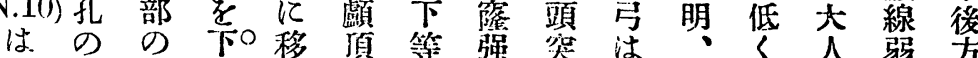
後倠傾 よ。

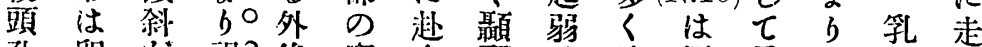

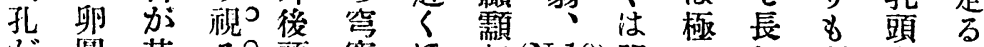

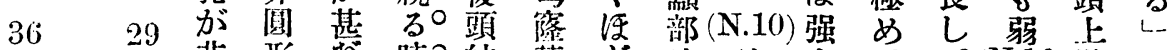

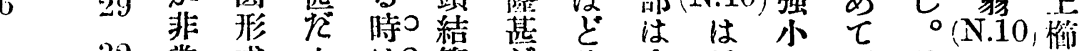

一 32 常或少は○節危狹中長供不前は中

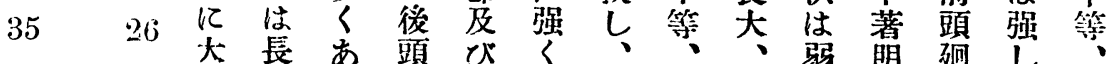

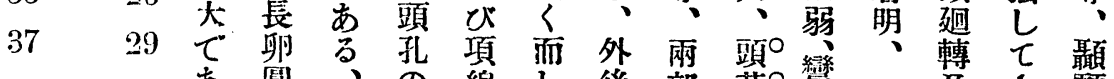

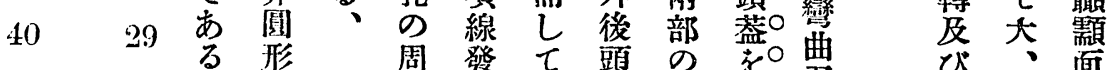

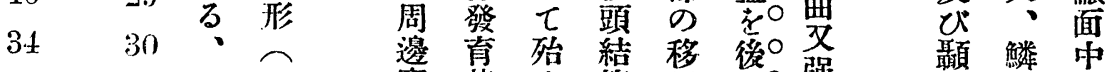

$36,429,2$ 二 個 穹 甚 $九$ 節 行 よ。强 就 牀 等

$\equiv$

$41 \quad 36$

小 等 强 境 垻 除 䘽 $(N \cdot 10)$

兒等し、界項々 る 時。

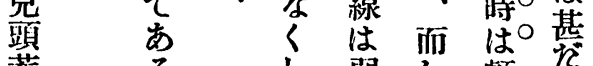

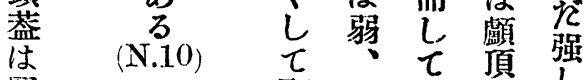

圓は

は 顳 $\bigcirc$ 後 部

迢 部 犬

の 或 以

隆は上

起中尘

弱 等 供

小高に

供在 
日十二月五年十四治明

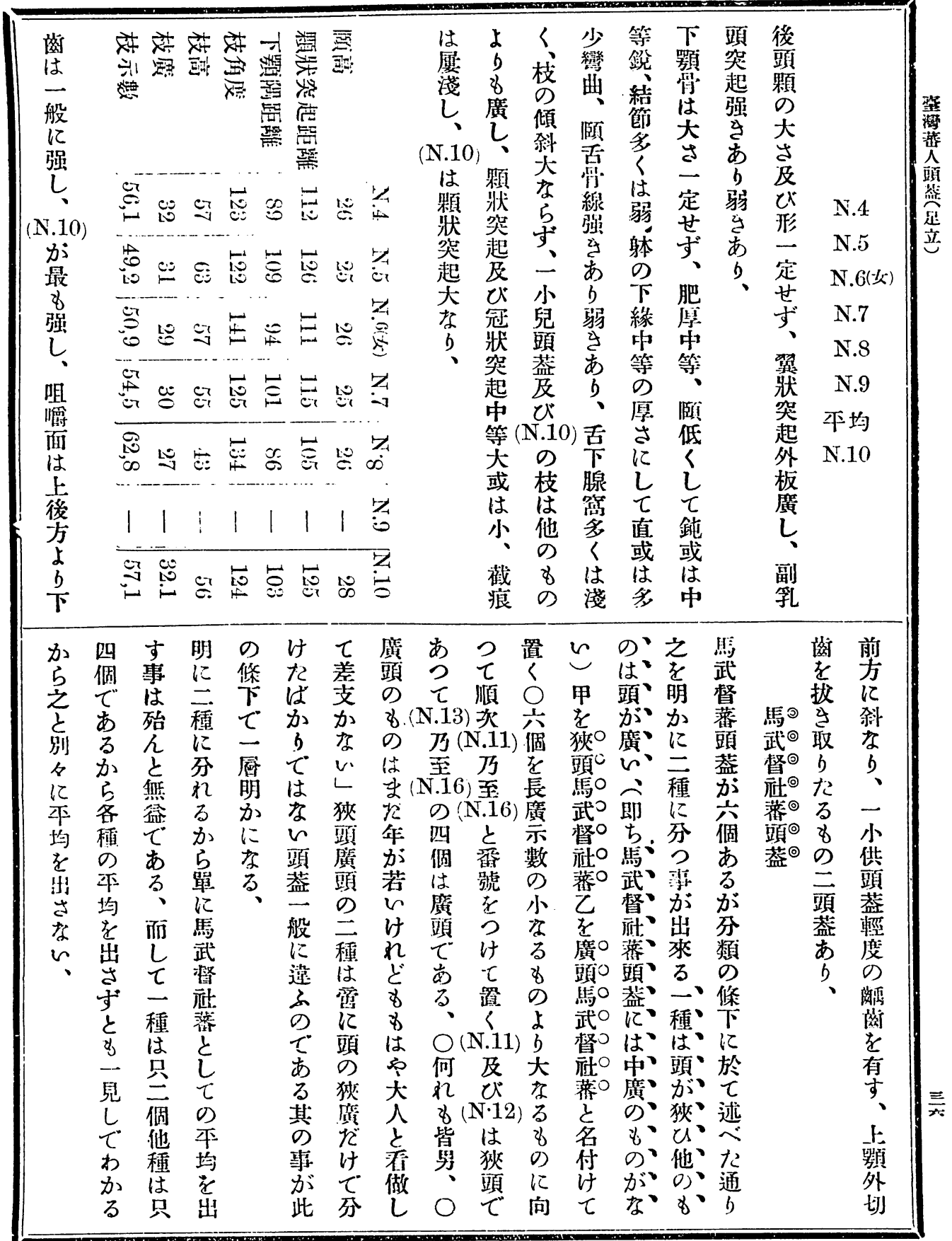


號四十五百二第誌雜會遙類人京東

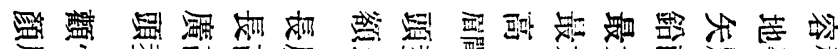

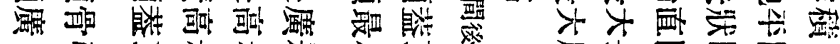

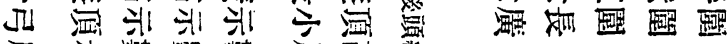

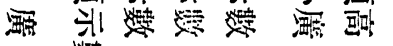
(4)

然

○

๑.

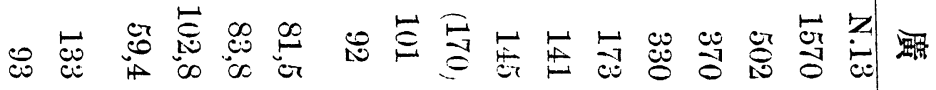

क

๑

官

法 あ 狹 㚘 万頭 に 示令頭 數 次 蓋

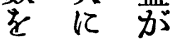
揭 頭 重 げ䜮く 万 全 $\tau$ 體 頝 の 固 大、 さ廣 科 頭 に 種

形は 此 知 の 万 點 k 必於 要 $\tau$ 中 る 等

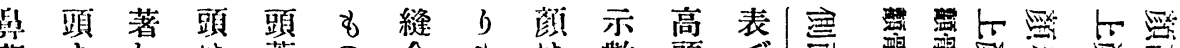

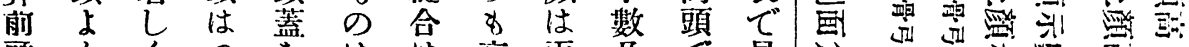

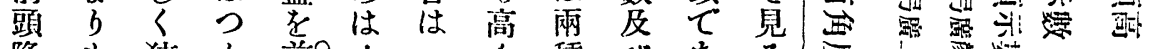

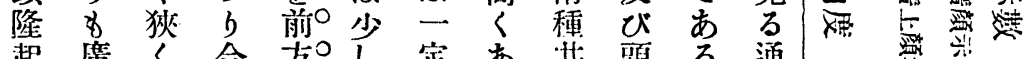

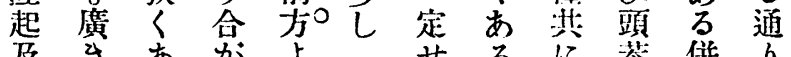

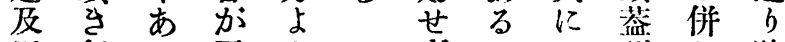

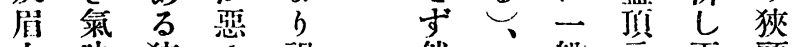
上味 狹く視然般示兩頭 弓加頭极る れ はあはととど低吕を廣 㷋方顴 $\bigcirc$ 陝名必比頭

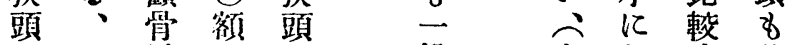
に 弓 $は$ は 在饾 亭廣比 は 加狹 し 强頭 頭 $\tau$ くの の 綮 廣廣 内务 に 比 個 で に 在 b 乙 $(\mathrm{N} .12)$ 京 廣は䫐

般尤し等

に $8 \tau$ 万

中 $(\mathrm{N} \cdot 15)$ 厝と頭

等は高狹 葐

或上示頭茄

は 顎 數

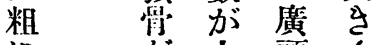

に 加大頭了

し 他灾

て の

密尔专長文

る

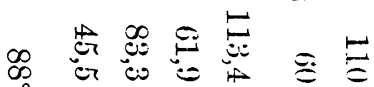

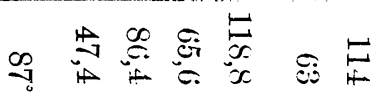

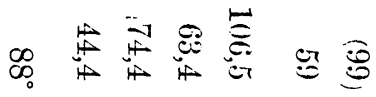
ठ요

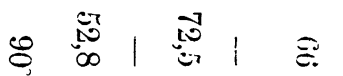

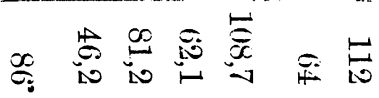




\section{日十二月五年十四治明}

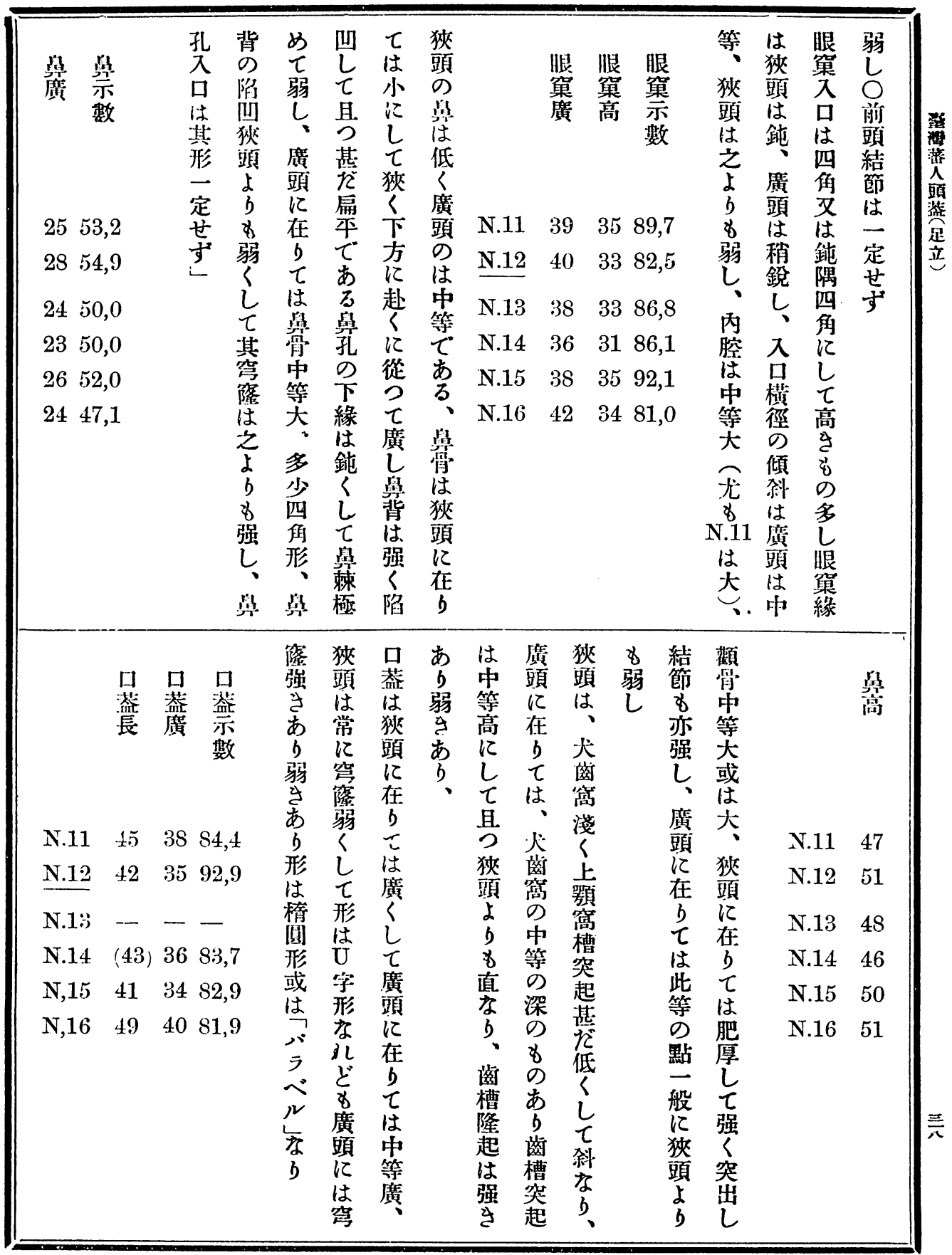


號四十五百二第誌雅會學類人京東

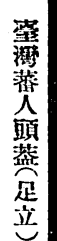

頭 し、狄 部 等 乳 狄 と

狄 $\tau$ 而 後

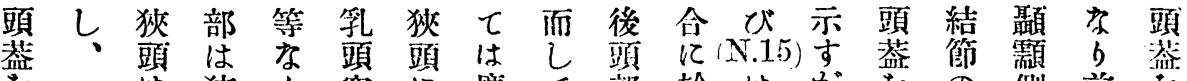

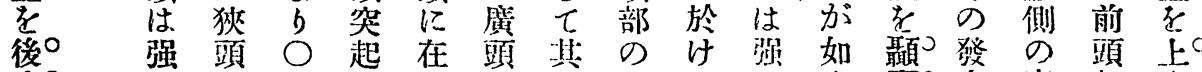

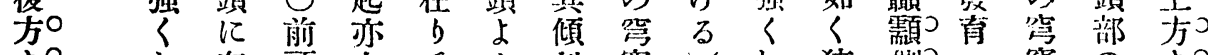

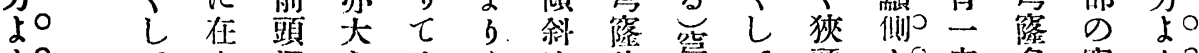

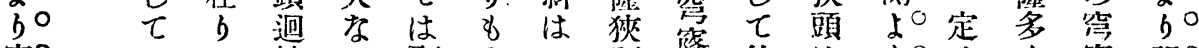

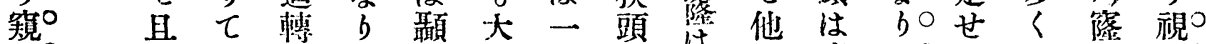

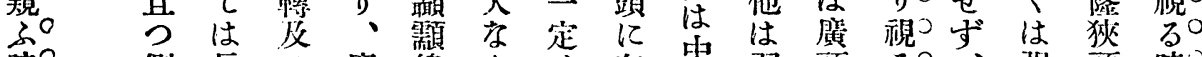

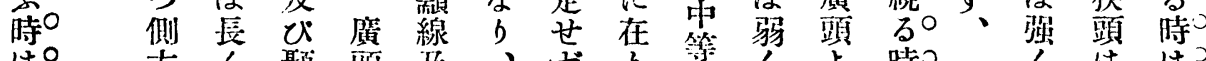

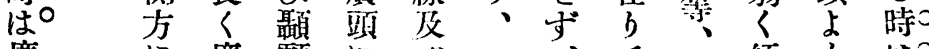

廣演 顬に ど

高 笑 頭 䢙 在 乳

示出に轉 b 頭

數 す 在のて上

另鹿 b 隆法櫛

示站 $\tau$ 起此强

す 蛙はは筞く

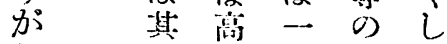

如

<

狄

䫑

は

磨
、乙 傾 傾 b は0

上は倾斜尚配

鱗强は种は低に

牀々 狹中广 長

部膺頭等 $\bigcirc$ 萿

の䫓頭、前示

傾に度㖽頭数

斜在廣損骨䒚

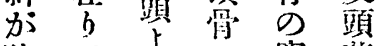

狹七占骂渠

䫓は年管頂

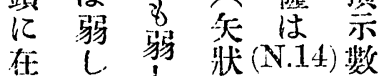

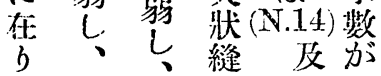

くははつ

後 弱 狹

頭く頙

の 廣は

写頭 細

隆は囻

多强 形

ये

はあ市

中 b 檱

等 畅 頭

\は

○昰 卯

覻 b [ [1]

頂、形
乙 度し 下。 乫 後

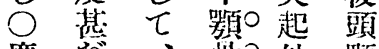

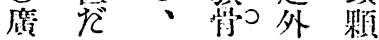

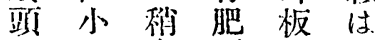

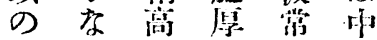
下 b < 记等

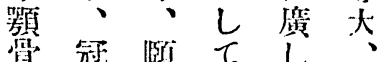

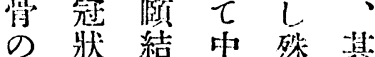
狄 哭 節 等 侀 頭起中大狄種

之 及 等 0 顕 名 異 ひ大 猍に、 點獎下頭 於 副 點 牀 下 緣 は 枝起彎 筋

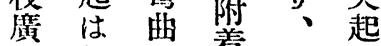

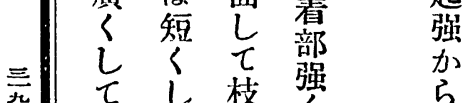
筋元 忮 尖

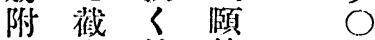
着痕枝鈍翼

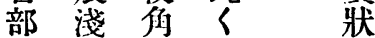

㷋 b $\bigcirc$ 其之側頭

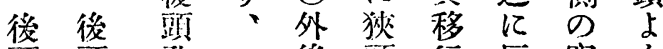

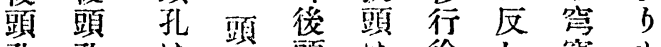

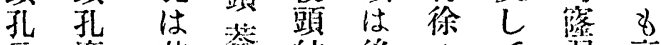

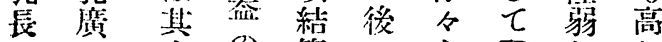

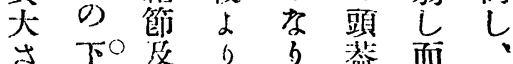
咯 面 ${ }^{\circ}$ 涀文頂し 頭 一真

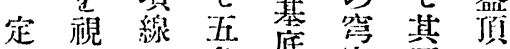
しる住角管雨合

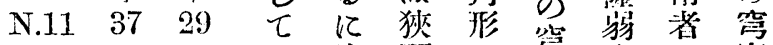
N.12 3730 居後䫓に䇥くの 滗 る 頭注し祭し移狄

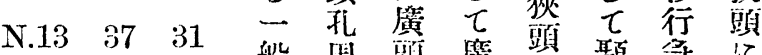

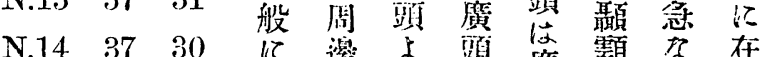

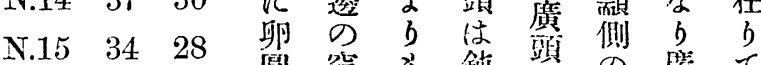

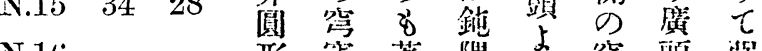

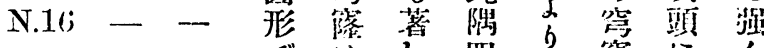
では し る 定强形弱它 于゙な 5 故ししは顠 
今侀く似○元分の詳此

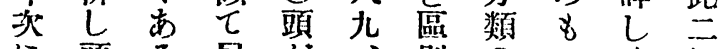

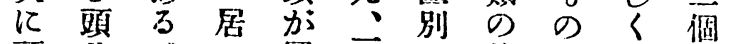

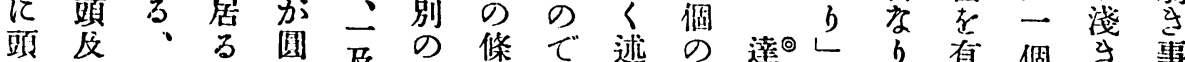

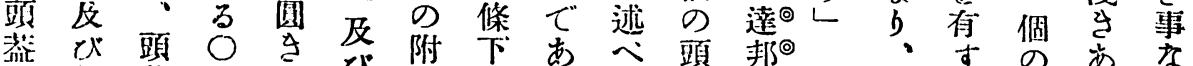

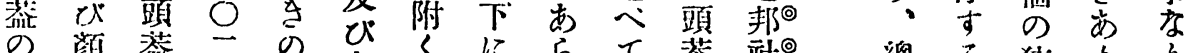

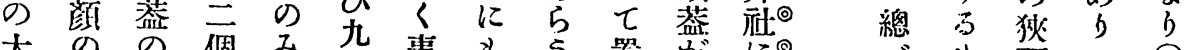

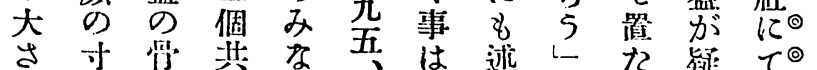

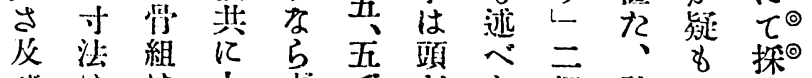

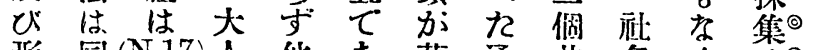

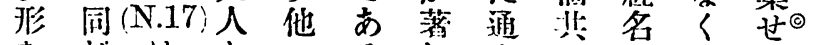

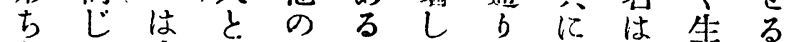

で中し諸、人此男明筷生

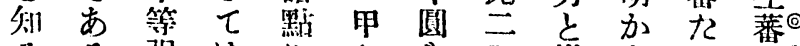

るる强は江名個推なる顠

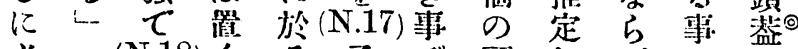

必 (N.18) る こで頍しでは

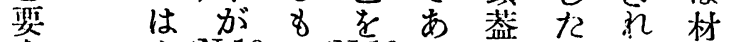

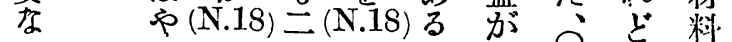

万艺は個と、他甬务

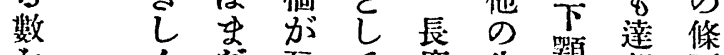

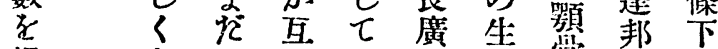

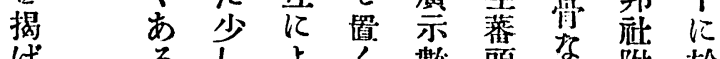

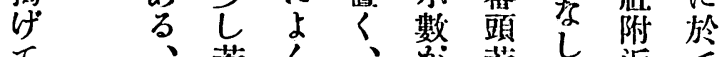

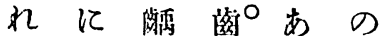

ベ \& 頭

$\tau$ の $(\mathrm{N} .12)$ 陌

の - (N.12) 舌

頭個は

蓝 あ 他

に $\quad b \quad 0$

於:

坚

步嚼

顎 喕 b

のは

外 後 继

切占店

蓄强

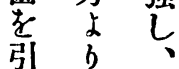

前 輕

拢禁度

線

$\tau$

卖

葲

深

a
は

频

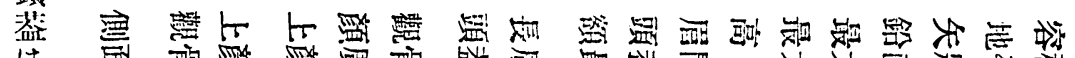

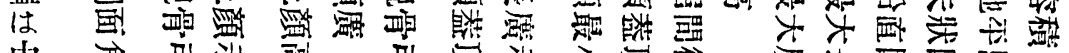

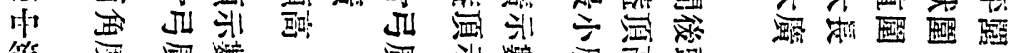

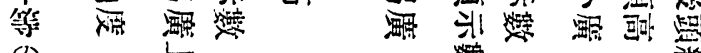

炎算

に

流

$\tau$

踒

め

$\tau$

琵

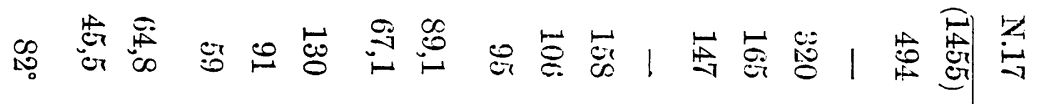

頭

㟟

顶

繁

亿

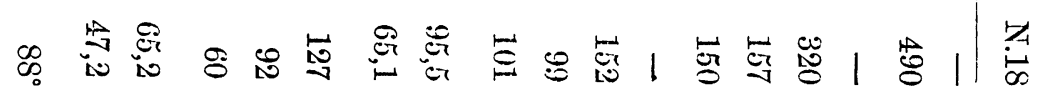


號四十五百二第誌唯會學類人京東

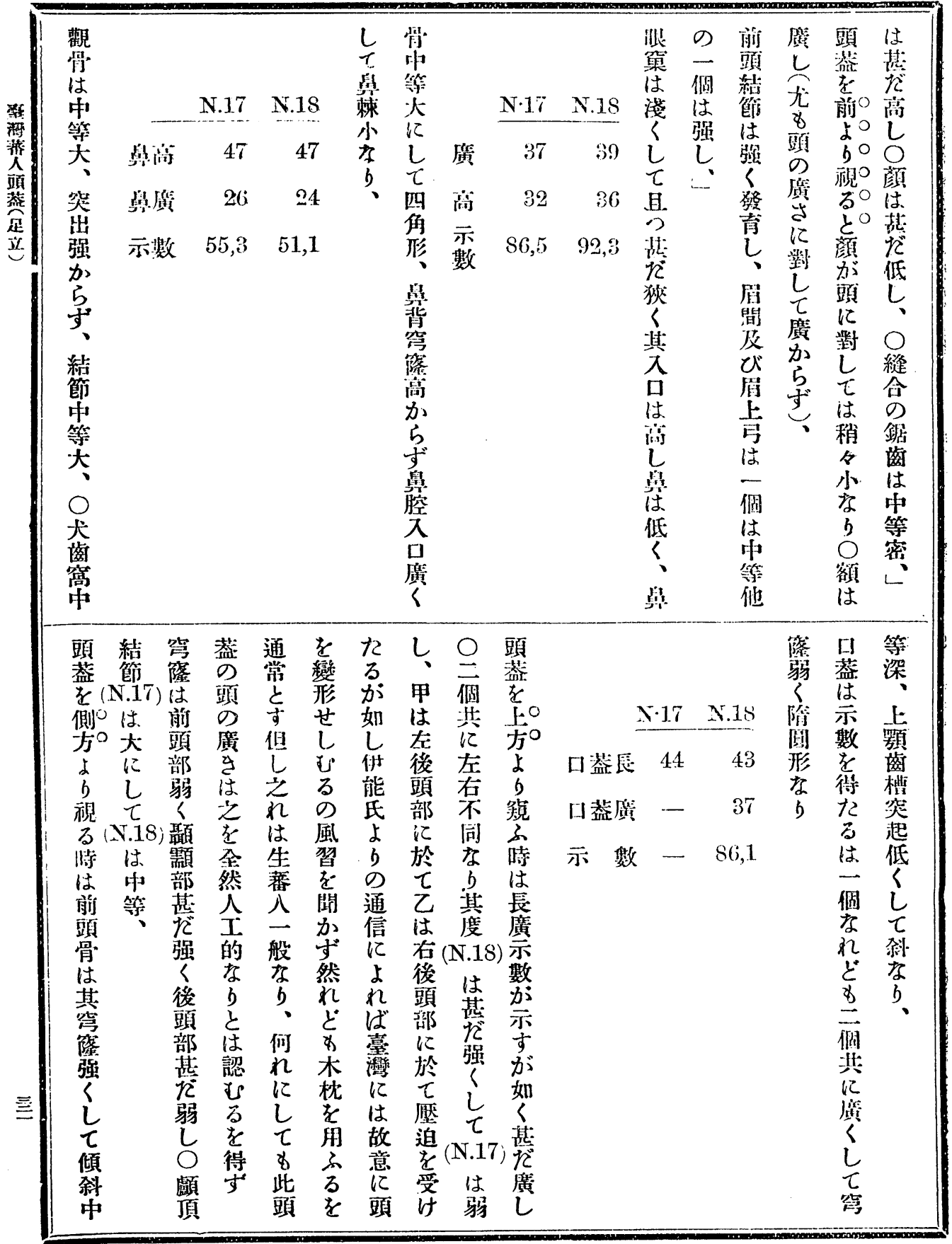




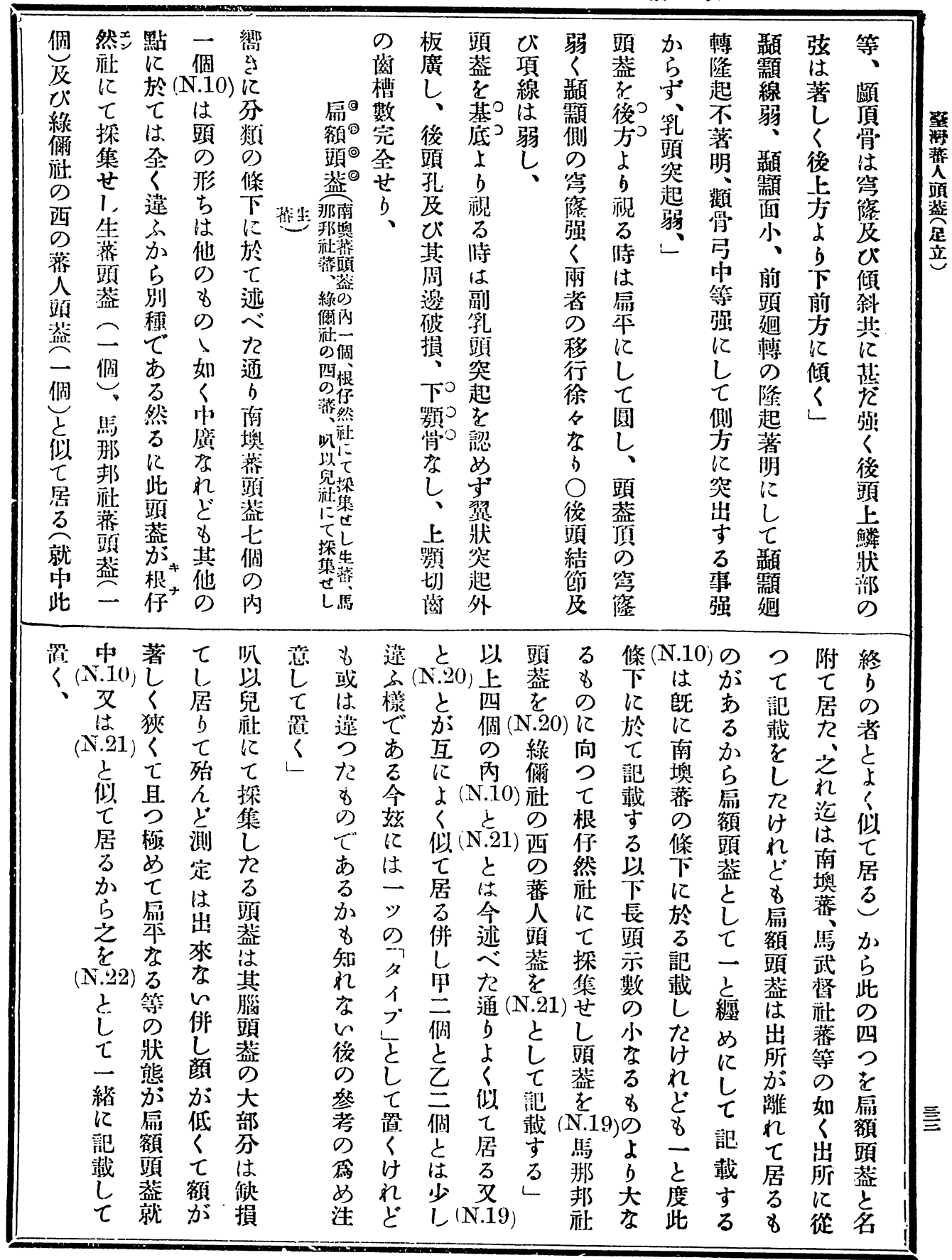


號四十五百二第誌䧴會學類人京東

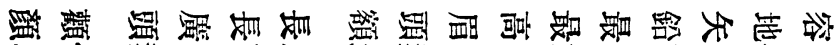

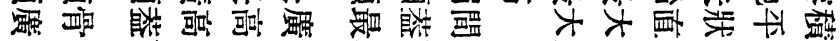

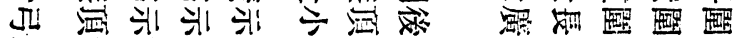

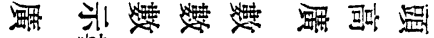
望

$$
\text { 数 }
$$

を今 以

揭次上

けに五

$\tau$ 頭 個

置 莘何

くの れ

大 8

さ大

景人

•ம

ち 或

司

点文

ம)

㢂

门 推

必定

要 し

な⿰

3 8

數 の

及 て

びあ

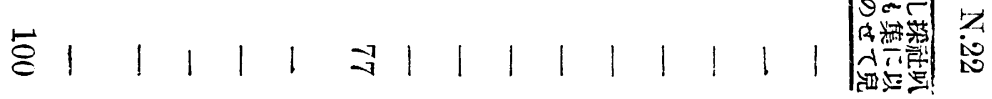

示る

數 ᄂ

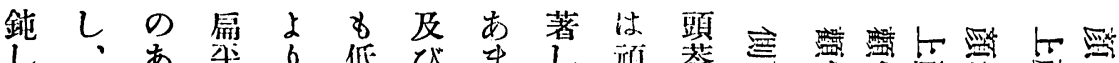

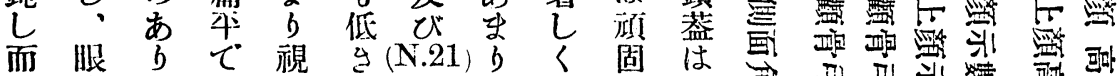

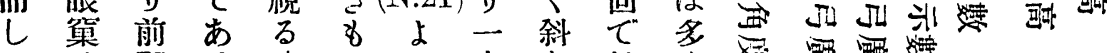

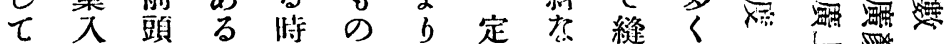

内口結 $○$ はな 8 世 b 合は は 尔

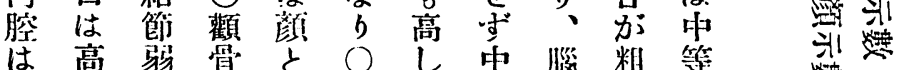

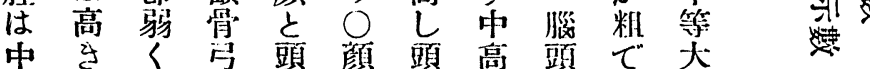

筹市 し

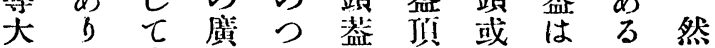

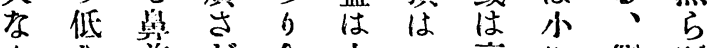

b前加合大一高に侧ざ

あ頭頭宜に般䰝し面れ

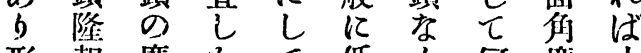

形起廣吕元低b何度小

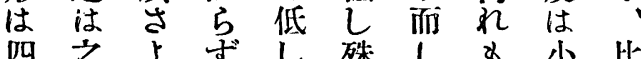

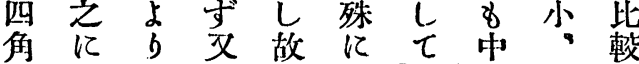

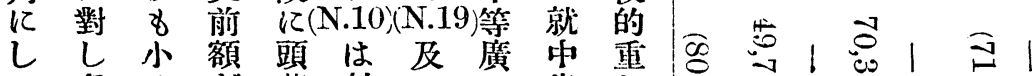

$\tau$ 多さ加䓝 材 ひ 、 莮

其くな 狹学料(N.20)高槽

緣はるく前中は哭婴

は强各 $\tau$ 方最 $(\mathbf{N} .10)$ は起組 


\section{日十二日五年十四治明}

は 前䫑窘 b 乫 顴

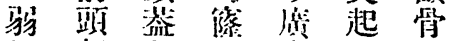

し蔀をは多肥

弱上躬あ, 大

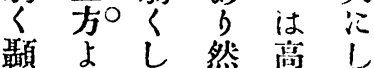

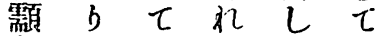

部 配 U ど 然 强

中 る 字 ऊ れ

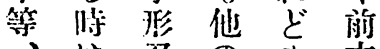

、は文の方

後中は灌芘に

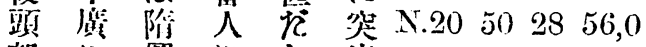

部に圆にし出

はし 形比く立

强七去方科 0

L 卵 b る 尔 犬 N.21(53)26 49,1

○间。洔 b 㓙

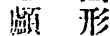

頂 な

維b

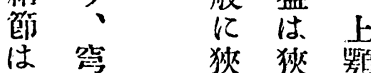

多簿 ᄂ 号菼 a $=$ に

悬異ししは 滆噟 数 $\tau$ 一

下 鈍 般

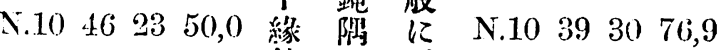

鈍 杵 低

的

艾素 N.19 363391,7

は陷

庶溉

只强

卯<N.20 38 3592,1

[激し

形 $\tau$

あ 䛿

b $\quad$ 本 $\quad$ N.21 $3937 \quad 94,9$

小

蓦 b

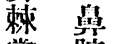

嫦 腔 N.22 $41 \quad 3585,4$

に入

背 口

た は

小低

㮌溚

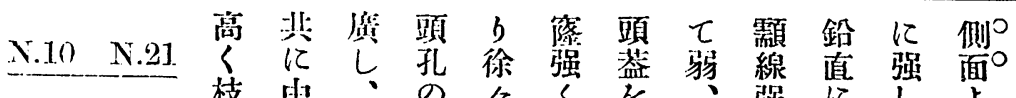

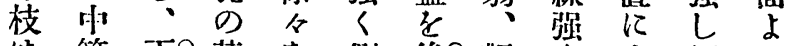

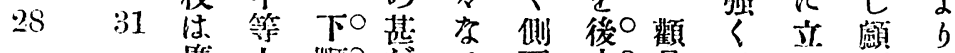

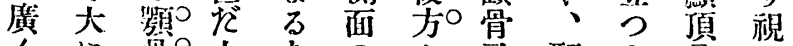

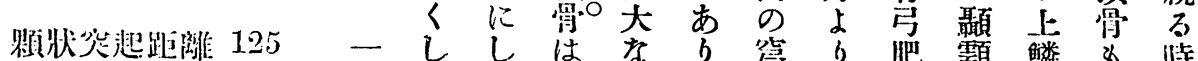
てて只る。管視厚面䔸亦は

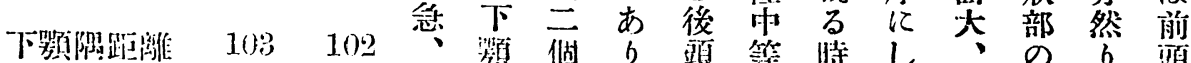
们 湔

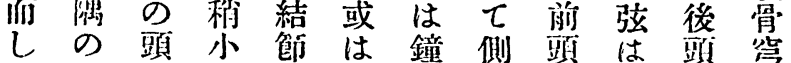

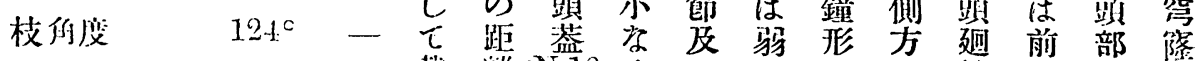
截 湤(N.10) る U

枝蓠

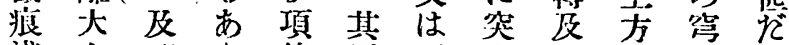

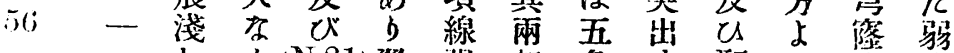

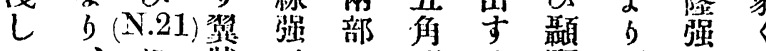

枝篗

$32 \quad 37$

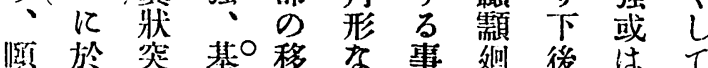

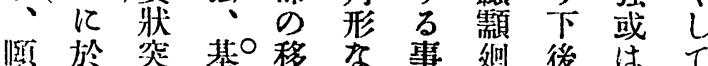
はて 起底行 $b$ 强軖方方具 枝示數 57.1 鏠存外に秒 颛 くす板 於急 蘊 しるは賏 ての 峭はるの 稍みに後あ学 隆走等 傾 起 万 们 斜

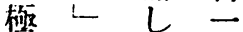
め顥 $\tau$ 般 
號四十五白二第䛱稚會學類人京車

鼻 此鼻六前 頭

莿盆密頭葐

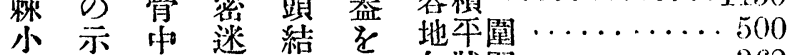

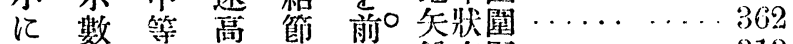

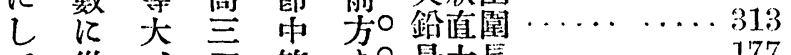

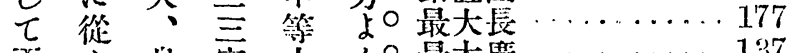

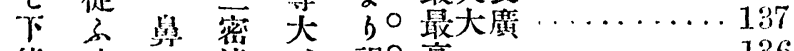

紸待市迷

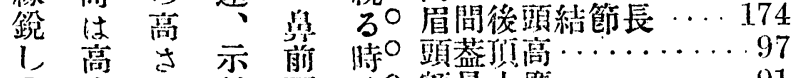

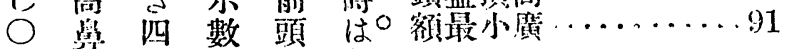

鹳㐋七九隆颜

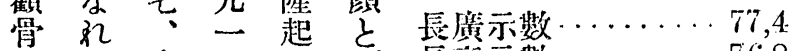

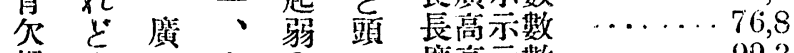

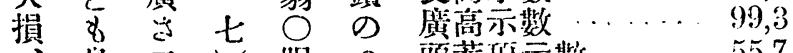

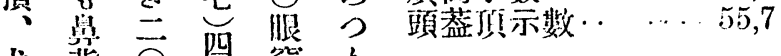

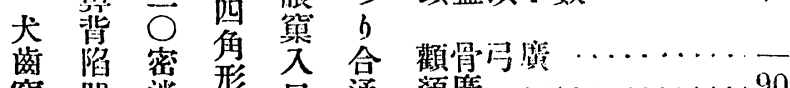

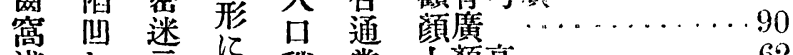

淺し 示 $し$ 稍常 上湎高……....62

々 $\tau$ 數 $\tau$ 高 額 上顏示數 ..........68,9

上象四緣く

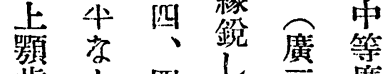

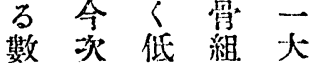

及に名䋶人

び此 万固 男

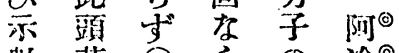

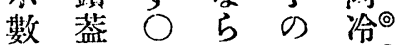

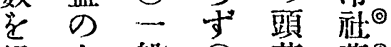

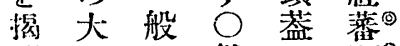

さ 分縫 (N.23) 頭间

及 狀 合 ${ }^{(N .23}$, 蓋

证熊は

万南 O 蕷

埃顽 骨

知菜は索

るに中 有

部似等 せ

に蕧和

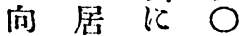

$\Rightarrow$ 万仡

$\tau \leftarrow \tau$ 頭

の 䫇

必名

要著艺
し 翰 大

七・补人

榙。罗

高附 千

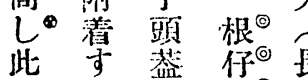

點 。 䇤 ${ }^{\circ}$ 四

记䫄 個 社 ${ }^{\circ}$

放"蓋 (N.24) 蕃。

で隹

は大 0 临

南に下

庄 $乙$ 鹳

菲七 骨

に重䗆

仩く存

乙 骨 ᄂ

居 組 榙

告强所

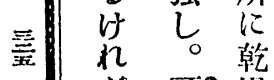

ど 顕・燥

के

他 诙。㕲

密

溧

\section{$\tau$ 基 ${ }^{\circ}$ 雨}

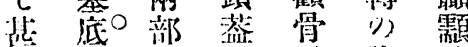

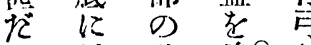

大於移後破

七 行 方 ${ }^{\circ}$

徐

後

醋

基

部

龍

强 愐 及

翼く線び

狀 後 弱 㩆

等 頭 暍

起 和

外 長

板 卵

廣 圆

加 形

卢
隆線

起

造弱 部

稍〈は必

明

ᄂ

後留䕱名

㽬㭙 起

势乳虫

记頭 等

ぞ上に骨

क 枌 ᄂ 莨

腼稍て

黟 强 倾

佪、杼

軠 顴 弱 骨

$の$ 頻 し

终面

起中

は 等

明大

分:

势 前

妾題
颉 密 槽

蓋 迷 管

赤 起

上擞 低

方公く

L

$b 、 \tau$

䅐七塗

はる屯存

强竹驾

しは䇥

顱陮中

顶 劕

結 形

節 に

は し ラ

翋 た た

前 $N$

頭 形 長

部外四

范切

び 商

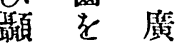

顠父四 


\section{日十二月五年十四治明}

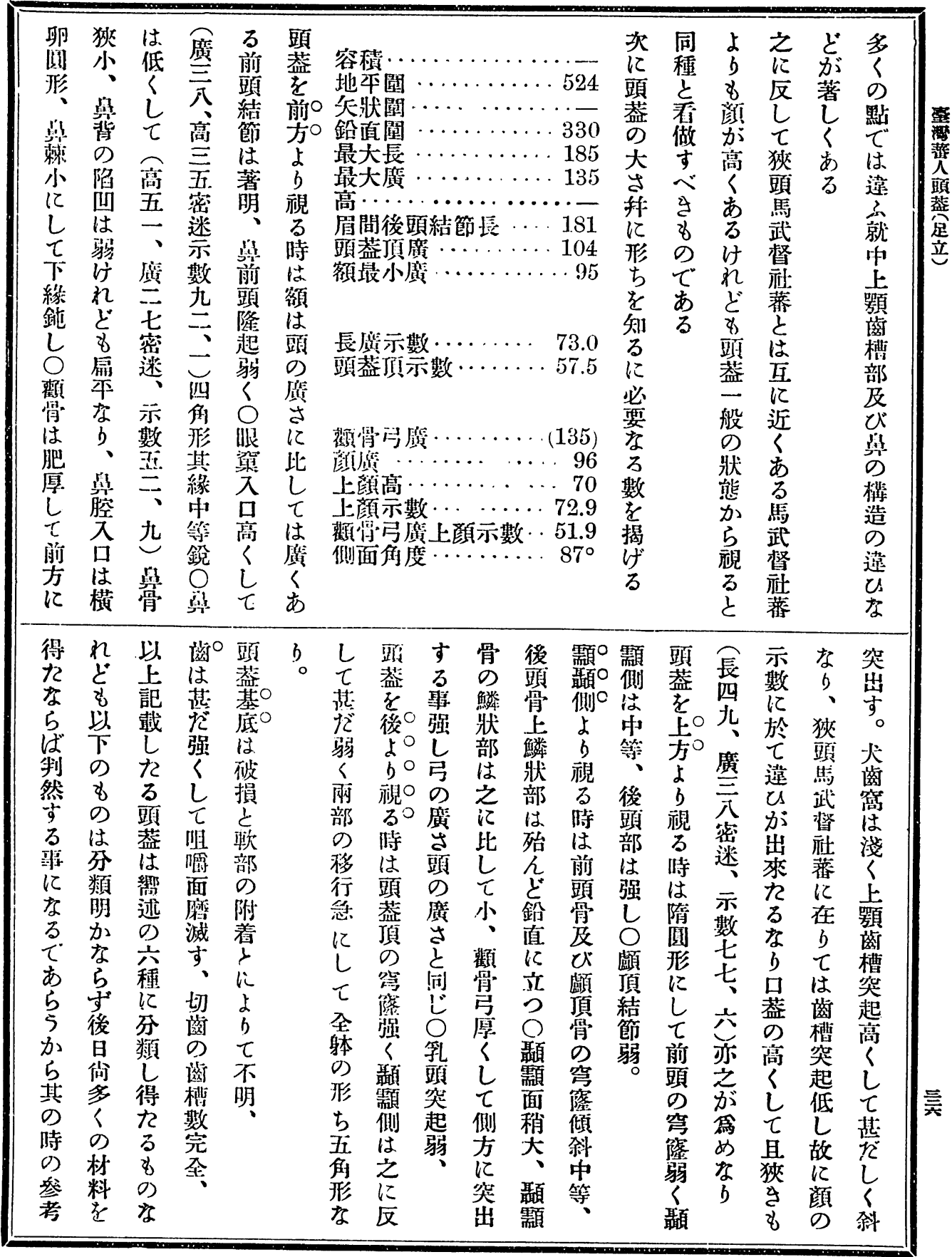


號四十五百二第誌馡會學類人宗東

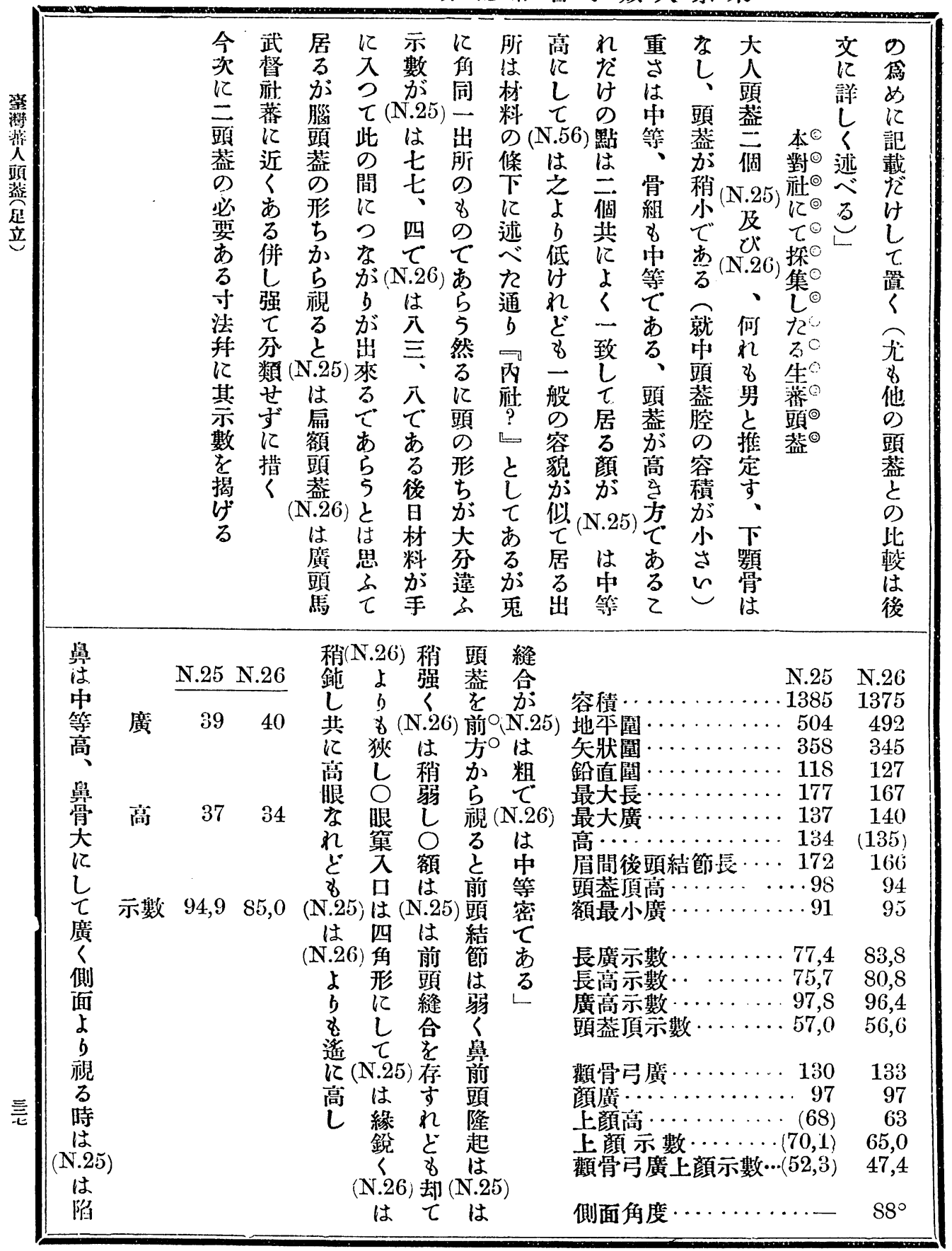


日十二月五年十四治明

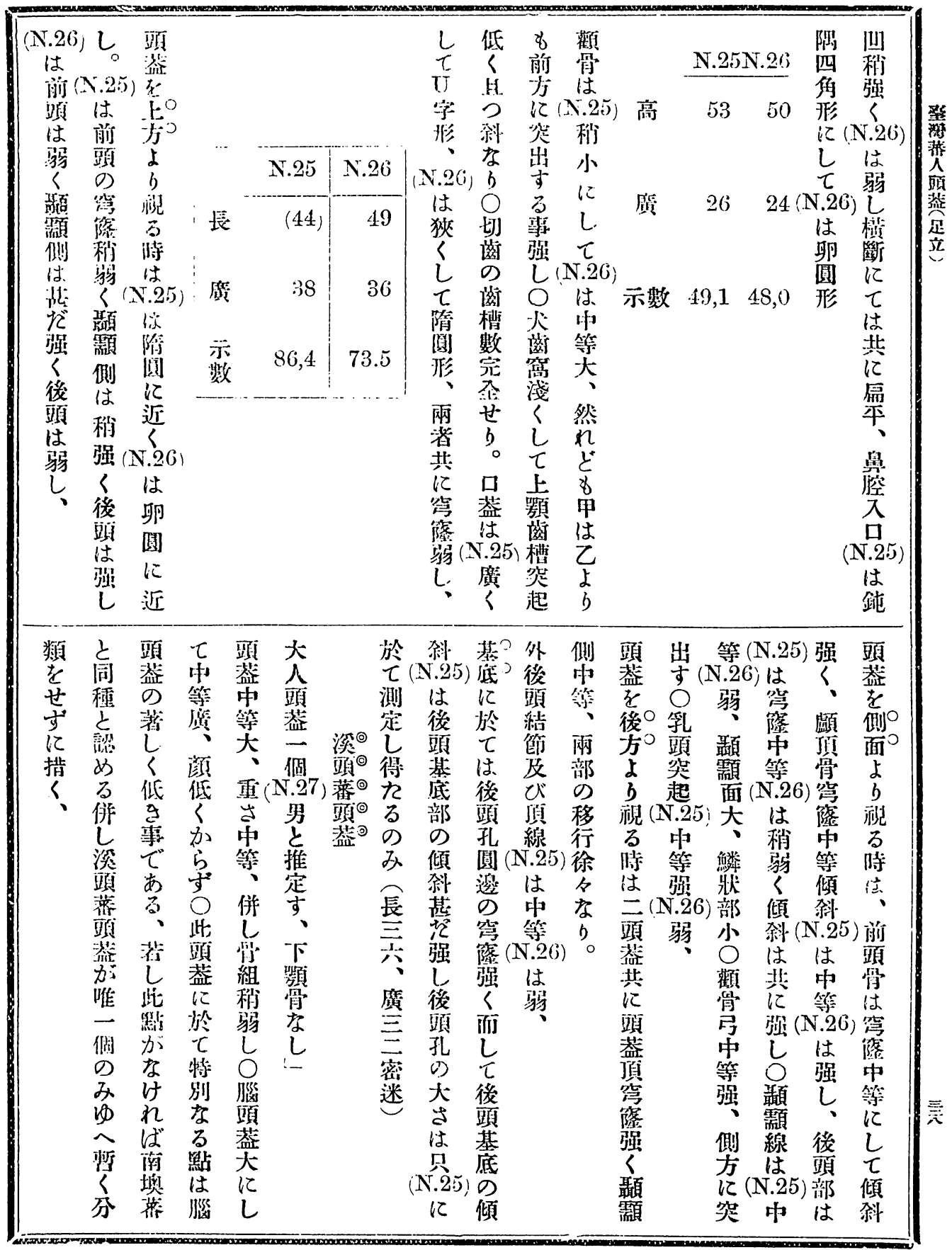


號四十五百二第誌雜會學類人京東

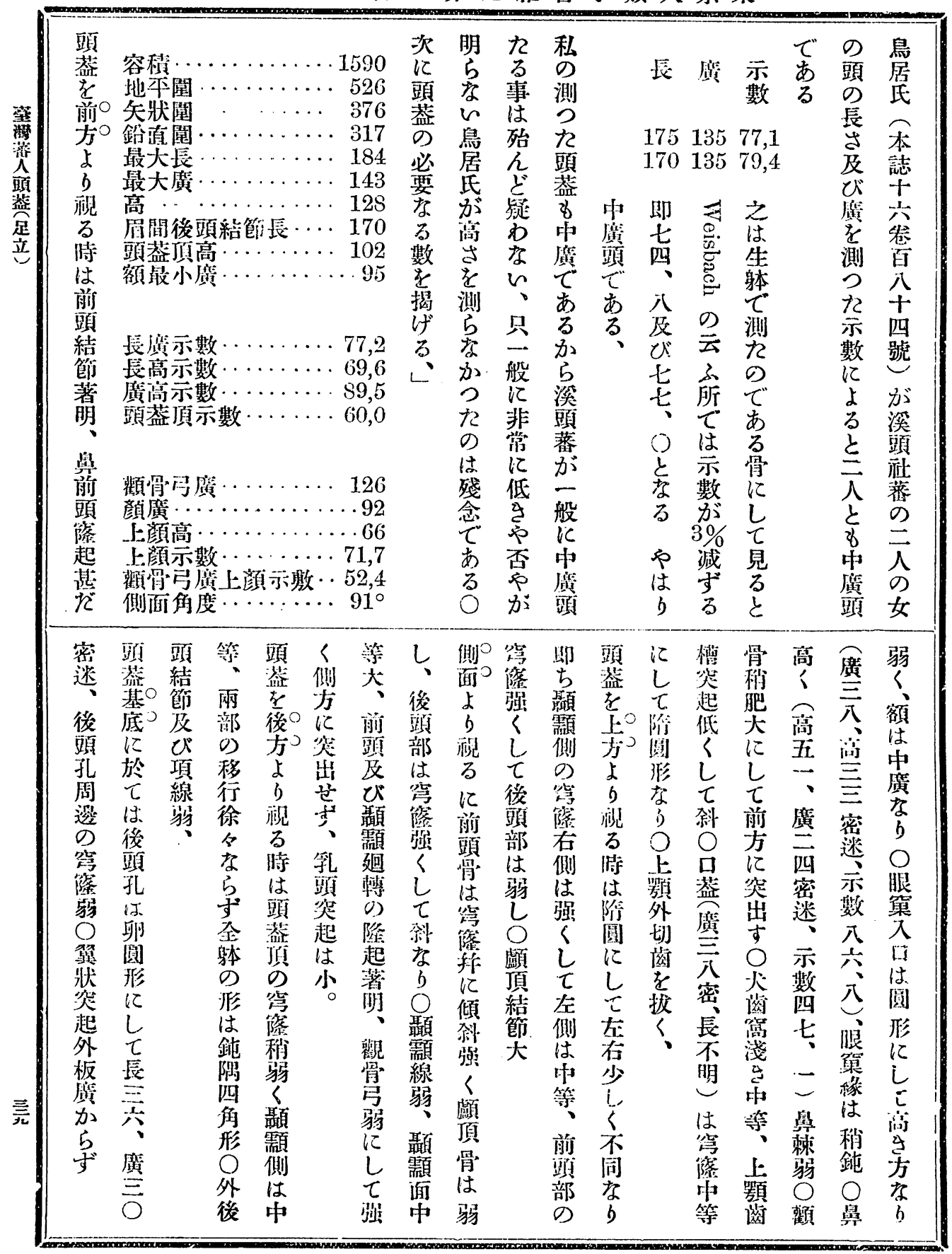




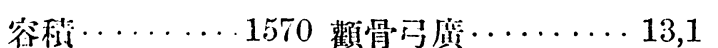

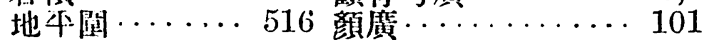

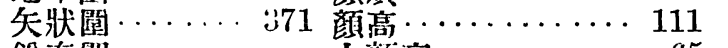

鉛淔閔 $\ldots \ldots \ldots \ldots$

叒大長 ................ 177

最大穈 ......... 137

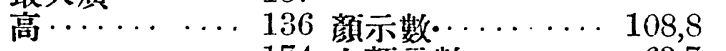

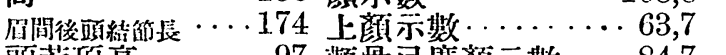

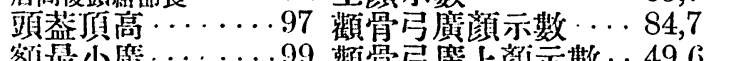

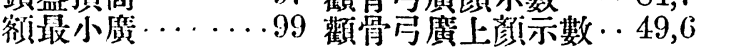

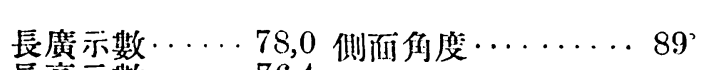

辰高示数 ……76,4

磨高示数 . . . . 97,9

证商顶示數…69,7
ずはは低をし㬡

○大䝻し見男人

綘な 额 ○市の 頭

合る 頭單 仓頭 荅

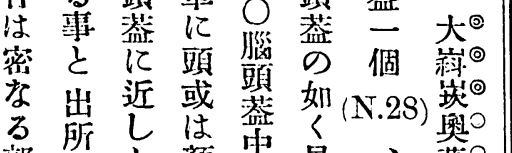

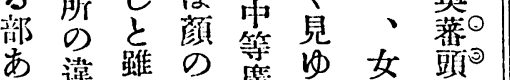

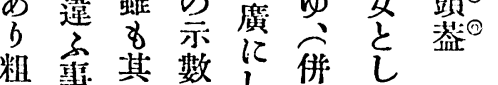

粗事其数学

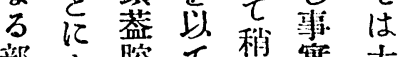

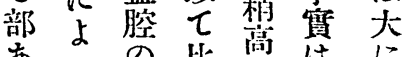

あ b 容较く漓にに

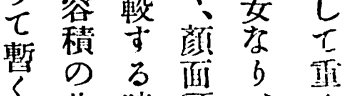

万面 $b$ Ifi

分紫は暗䕱材且

類に献大料?

に比墺にの 雷

加し菜し條組

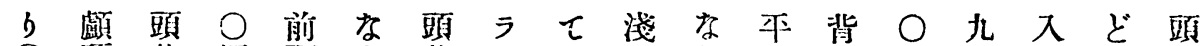

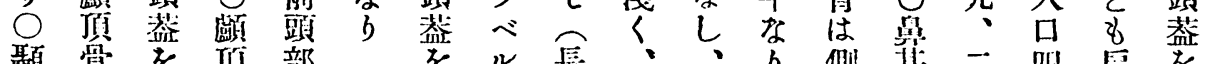

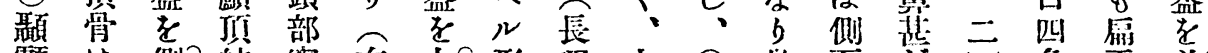

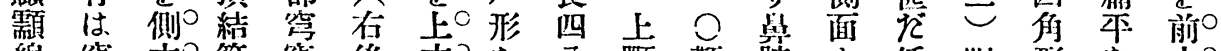

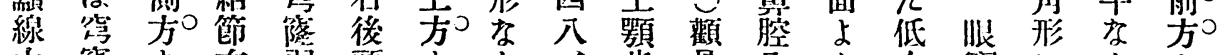

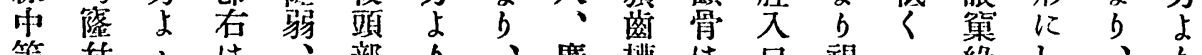
等 賚 $b$ は

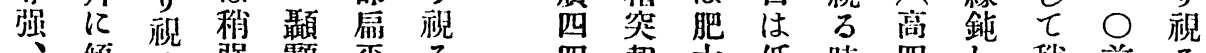

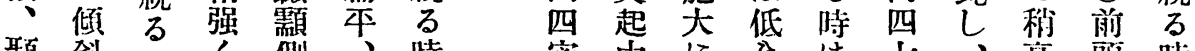

顳 斜 時く侧、時

䨘弱は左右左は。

面くはは前卵

稍後前稍强站国

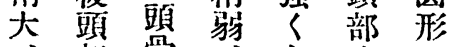

、部骨坊左多に

前圭第独し

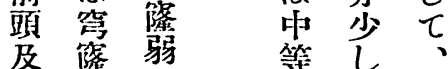

及 篮弱

稍く文

影强傾 後扇右

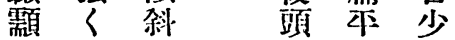

备 傾 等

轉 斜な

の 急 b
はなし

强 b
密畃に管は

迷等 し 卯陷

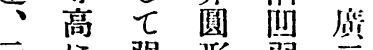

示に强形弱

数しくにく元

九七 前しし密

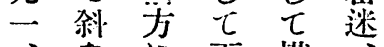

、をに下橫

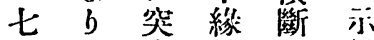

○ 出 鈍 寸 数

劣口すく至

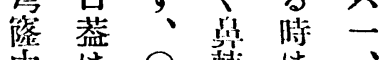

中は○噃は、

等 廣 尘殆 紧

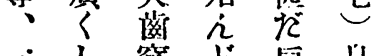

高頭 㭙

く絬は

節 烄

磨 强は

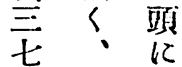

比

高 前 L

三軦 $\tau$

三隆大

速幥起额

、、は

示 ○㕍

數 眼 け

八笨风 
號四十五百二第誌雜會學類人京東

大弦

人 2 v

男

子报萔

的䬤行面

頭 尺๑れ少

佥 附 $\odot$ b

二 湎 ${ }^{\odot}$

個 の॰

$(\mathrm{N} .29)^{\text {告 }^{\circ}}$

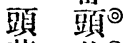

蔡 蓋

稍

小

骨

組

中

筞

相

蔥

佔

有

す
減枝高

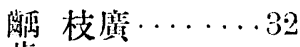

枝示數…56, 56

战

の

外

切

谈

願高

顾状突起距朔 - . 123

下韻隅距離 …101

枝解度…140

$\ldots \ldots 57$

2

(1)
枝

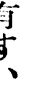

点

外

切

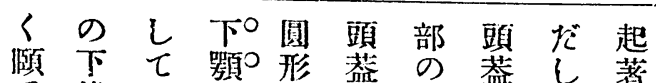

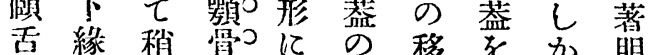
骨厚栱はし 基○行後口去

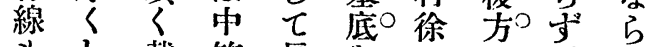

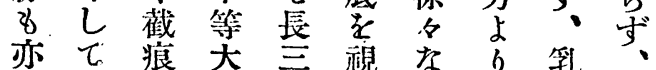
中少淺に无る 等しくしし、江 0 る 突骨

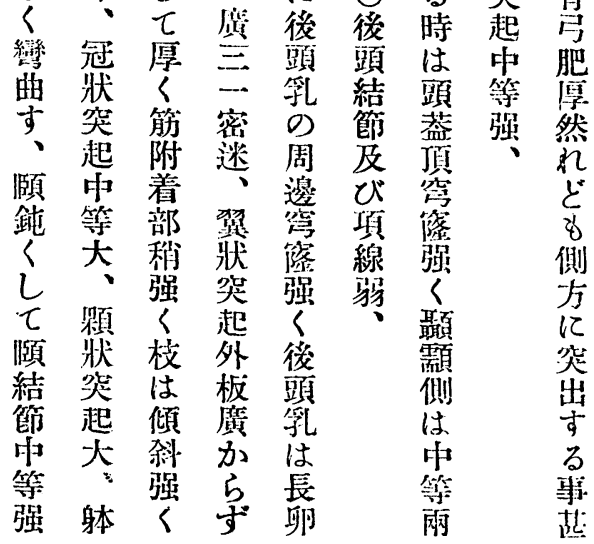

㰯 顽

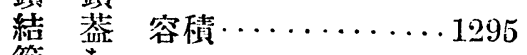

節 喜。地本闻…........4. 493

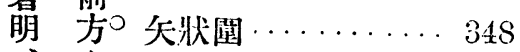

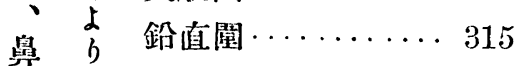

前 视 最大長…........ 167

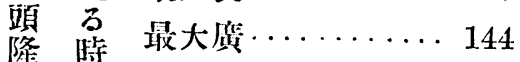

起は 高……....... 130

弱省 届問後頭結節長… 165

$\bigcirc$ 頭 頭䒸顶高 $\ldots \ldots \ldots \ldots 92$

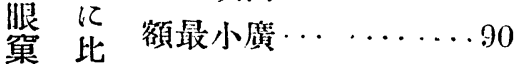

万兄

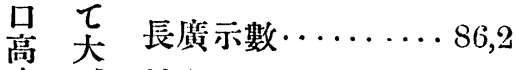

를

長高示数 ……777,8

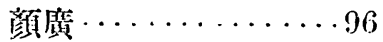

㥳高

小同に腦

な種し頭

る 2 滥 事看澶は

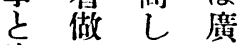

上顏高...........65 出 $L$ 頭 所 得 文 $L$ の び 造 ど剂 高

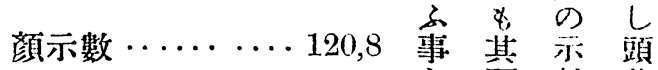

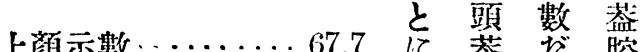

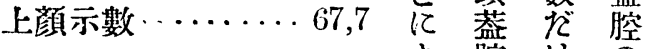

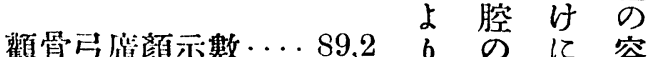
容 $\tau$ 棈

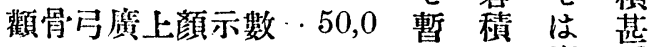

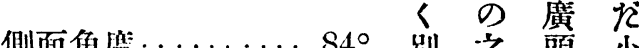
别之䌿尔 L $\quad b$ 武 頝 乙 督 頭 置 遥 社 荅 く加蕃は 


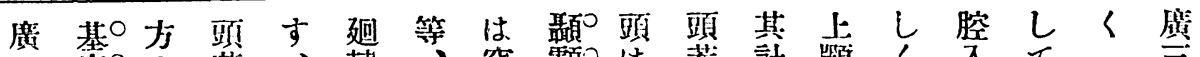
云底 の

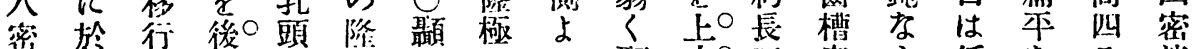

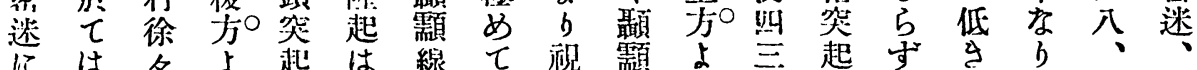

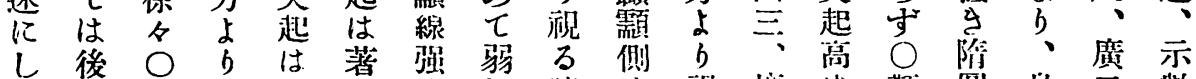

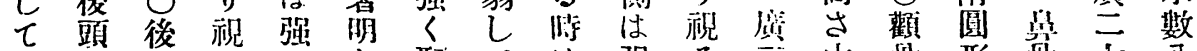

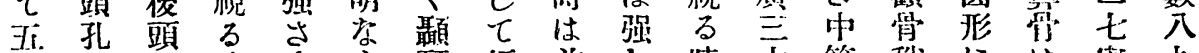

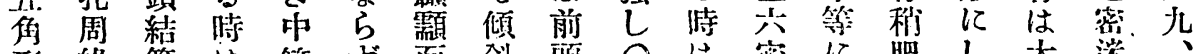

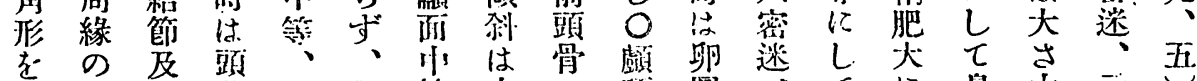

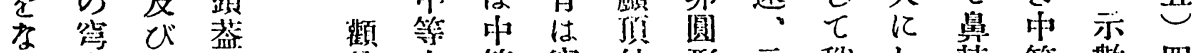

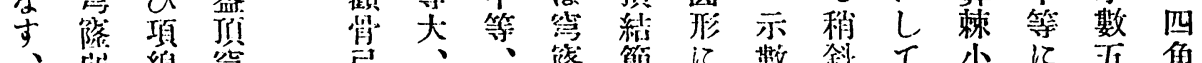

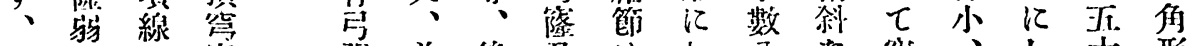
翼々强管

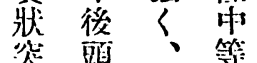
起 孔 外は頨 板長譻 は さ 侧 矿 强 ᄂ 三

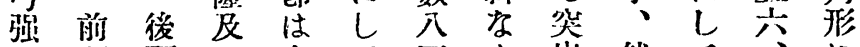

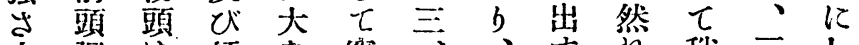

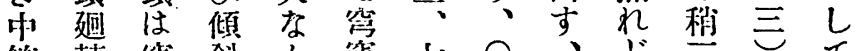

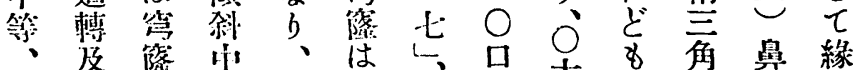

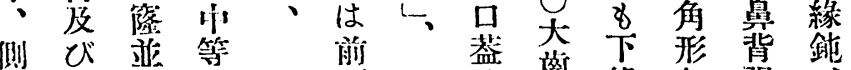

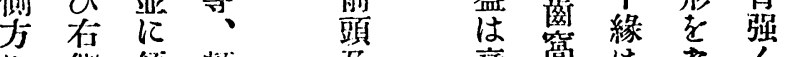

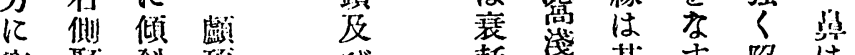

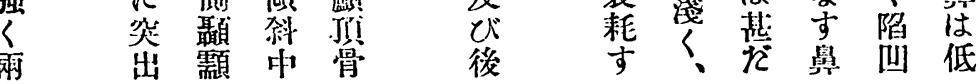

がは磨部大 示互籍 頭 冞人 数 に 䀡名く昌 茷蕃の 破 副 枟四 如損 䒸 78,1 近 人

79,6 中

79,7 頡 て 就 藏 廣 蓝

79,6 あ て 氏 示 秒 る 長 本 数 大 に此范誌不重

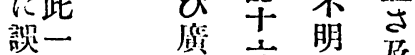

b列等六势支

むに 紊第犳少

bは 们 第 自組

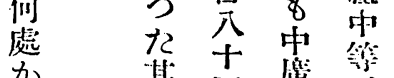

活 其四頭 後

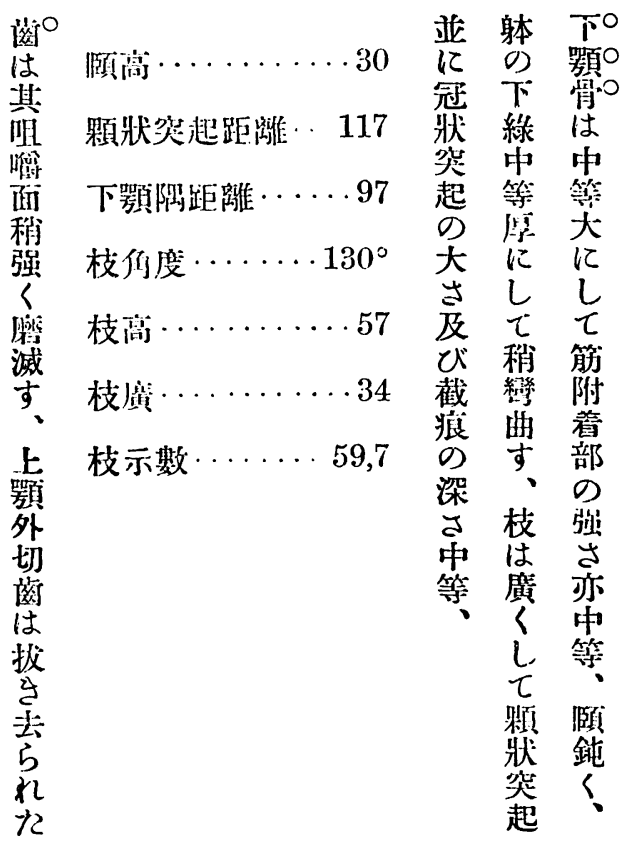


號四十五百二第誌﨎會學類人宗束

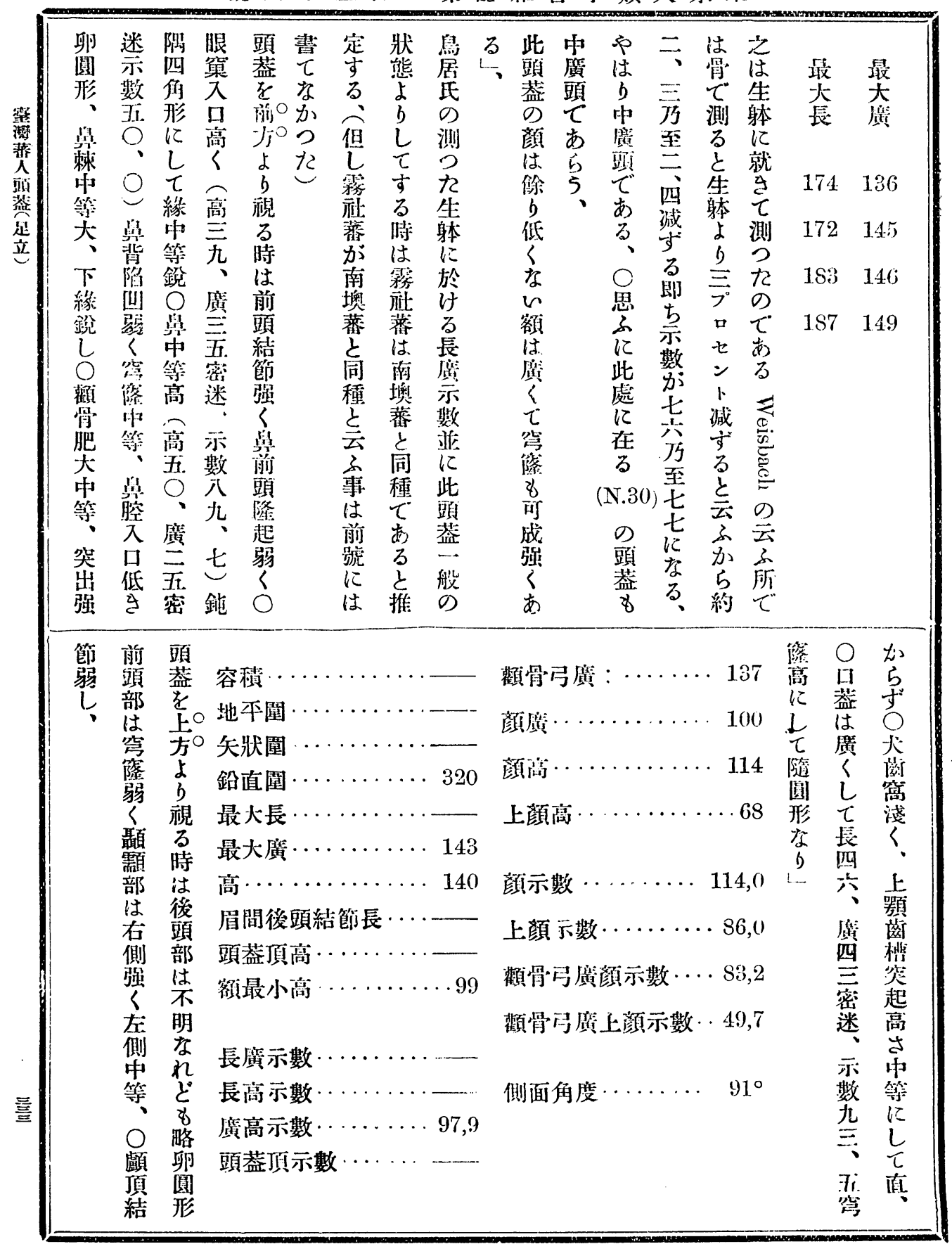


日十二月五. 年十四治明

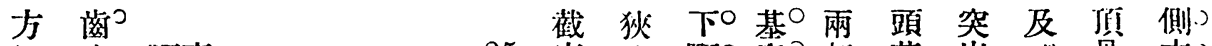

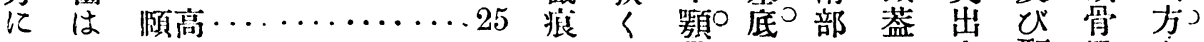

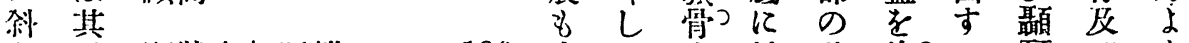

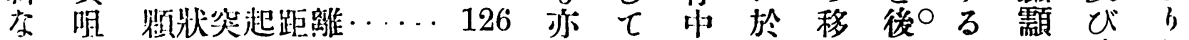

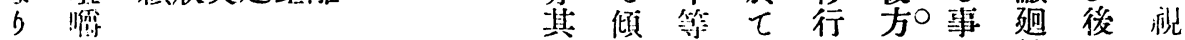

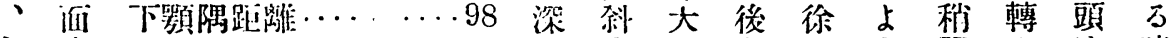

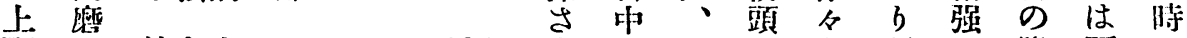

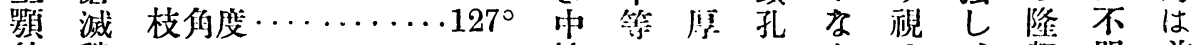

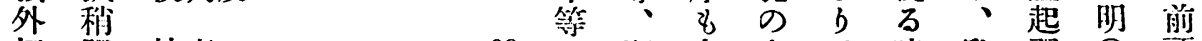

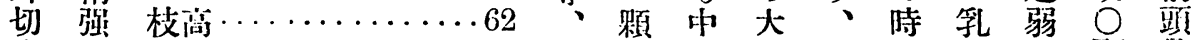

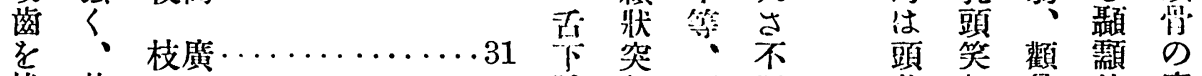

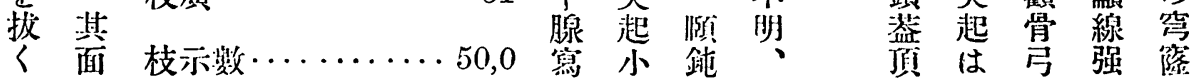

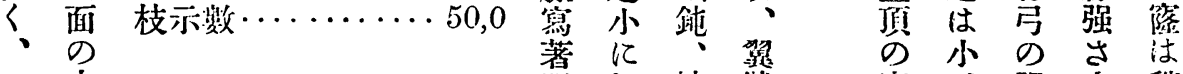

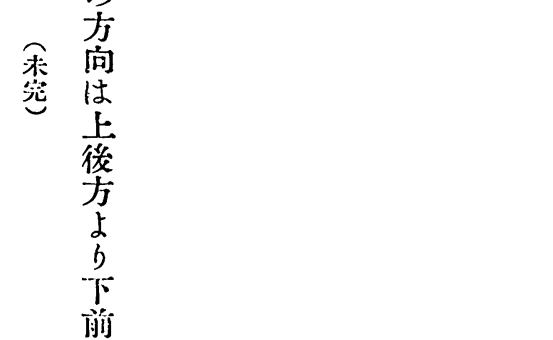

明乙射牀穹、强中利

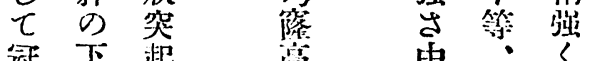

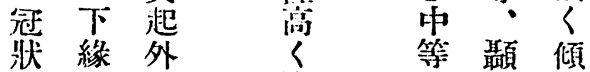

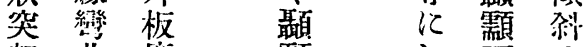

起曲噔顴し面は

中弱方侧侧高利

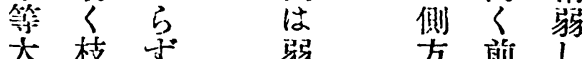

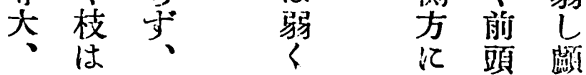

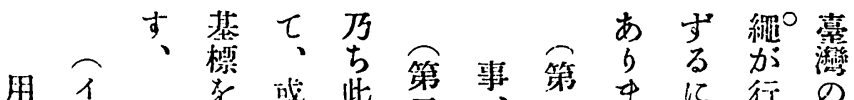

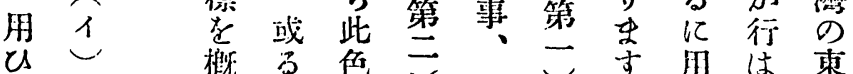

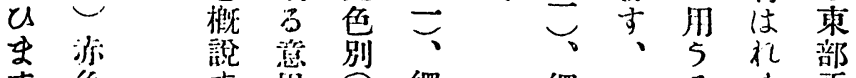

す, 啲

繩

は、

自

他

共

に

男

子

關

倸

の

意

思

の

素

に
古思管繩

れ第絰

は浐已

大示と、堅

繒 万結 結

左 符 別 び

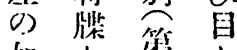

㚾箁 算

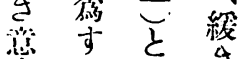

味

㞭节彼百

方基茈定

つ基卒忌

あ 符連造

あ 符 連

ま䈎戀事
㝗

は

胁

你

及

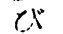

畟

齐

は

青

色

9

種

程

以

$\tau$

成
の 情 豐。
万势

3) 原

v) $、 k$

で踔卢

其 繩 守

ひ) る

成、

立

i $\frac{1}{2}$

次乙族

の $\tau$ r

$\begin{array}{llll}\text { の } & \text { 男 } & & \text { 結 } \\ \text { 㚾 } & \text { 女 } & \text { 能 繩 }\end{array}$

三間 種

の の

特 意 契生

色 的 